\title{
Review \\ Coriandrum sativum L.: A Review on Ethnopharmacology, Phytochemistry, and Cardiovascular Benefits
}

\author{
Nisa Najibah Mahleyuddin ${ }^{1,+}$, Said Moshawih ${ }^{1,+} \mathbb{D}$, Long Chiau Ming ${ }^{1}$, Hanis Hanum Zulkifly ${ }^{2}$, \\ Nurolaini Kifli ${ }^{1}$, Mei Jun Loy ${ }^{3}$, Md. Moklesur Rahman Sarker ${ }^{4}\left(\mathbb{D}\right.$, Yaser Mohammed Al-Worafi ${ }^{5,6}{ }^{\mathbb{D}}$, \\ Bey Hing Goh ${ }^{7,8} \mathbb{D}$, Shobna Thuraisingam ${ }^{9}$ and Hui Poh Goh ${ }^{1, *}$
}

1 PAP Rashidah Sa'adatul Bolkiah Institute of Health Sciences, Universiti Brunei Darussalam, Seri Begawan BE1410, Brunei; nisanjbh@gmail.com (N.N.M.); saeedmomo@hotmail.com (S.M.); long.ming@ubd.edu.bn (L.C.M.); nurolaini.kifli@ubd.edu.bn (N.K.)

2 Faculty of Pharmacy, Universiti Teknologi MARA, Shah Alam 42300, Malaysia; hanish2984@uitm.edu.my

3 Faculty of Engineering, Universiti Teknologi Malaysia, Johor Bahru 81310, Malaysia; junmeiloy@gmail.com

4 Department of Pharmacy, State University of Bangladesh, Dhaka 1205, Bangladesh; moklesur2002@yahoo.com

5 College of Medical Sciences, Azal University for Human Development, Amran P.O. Box 447, Yemen; yworafi@yahoo.com

6 College of Pharmacy, University of Science and Technology of Fujairah, Fujairah P.O. Box 2202, United Arab Emirates

7 Biofunctional Molecule Exploratory (BMEX) Research Group, School of Pharmacy, Monash University Malaysia, Subang Jaya 47500, Malaysia; goh.bey.hing@monash.edu

8 College of Pharmaceutical Sciences, Zhejiang University, Hangzhou 310058, China

9 Department of Chemistry, Faculty of Science, Universiti Putra Malaysia, Kuala Lumpur 43400, Malaysia; shobnasima@gmail.com

check for updates

Citation: Mahleyuddin, N.N.; Moshawih, S.; Ming, L.C.; Zulkifly, H.H.; Kifli, N.; Loy, M.J.; Sarker, M.M.R.; Al-Worafi, Y.M.; Goh, B.H.; Thuraisingam, S.; et al. Coriandrum sativum L.: A Review on Ethnopharmacology, Phytochemistry, and Cardiovascular Benefits. Molecules 2022, 27, 209. https:// doi.org/10.3390/molecules27010209

Academic Editor: Maria João Matos

Received: 26 November 2021

Accepted: 21 December 2021

Published: 30 December 2021

Publisher's Note: MDPI stays neutral with regard to jurisdictional claims in published maps and institutional affiliations.

Copyright: (c) 2021 by the authors Licensee MDPI, Basel, Switzerland. This article is an open access article distributed under the terms and conditions of the Creative Commons Attribution (CC BY) license (https:// creativecommons.org/licenses/by/ $4.0 /)$.
* Correspondence: pohhui.goh@ubd.edu.bn

+ These authors contributed equally to this work.

\begin{abstract}
Coriandrum sativum (C. sativum), belonging to the Apiaceae (Umbelliferae) family, is widely recognized for its uses in culinary and traditional medicine. C. sativum contains various phytochemicals such as polyphenols, vitamins, and many phytosterols, which account for its properties including anticancer, anti-inflammatory, antidiabetic, and analgesic effects. The cardiovascular benefits of $C$. sativum have not been summarized before, hence this review aims to further evaluate and discuss its effectiveness in cardiovascular diseases, according to the recent literature. An electronic search for literature was carried out using the following databases: PubMed, Scopus, Google Scholar, preprint platforms, and the Cochrane Database of Systematic Reviews. Articles were gathered from the inception of the database until August 2021. Moreover, the traditional uses and phytochemistry of coriander were surveyed in the original resources and summarized. As a result, most of the studies that cover cardiovascular benefits and fulfilled the eligibility criteria were in vivo, while only a few were in vitro and clinical studies. In conclusion, C. sativum can be deemed a functional food due to its wide range of cardiovascular benefits such as antihypertensive, anti-atherogenic, antiarrhythmic, hypolipidemic as well as cardioprotective effects.
\end{abstract}

Keywords: Coriandrum sativum; cardiovascular; coriander; antihypertensive; hypolipidemic; cardioprotective; functional food; ethnopharmacology

\section{Introduction}

Coriandrum sativum Linn. (C. sativum) or coriander, is recognized for its wide range of uses in culinary as well as traditional medicine in a variety of conditions [1]. Different chemical compounds have been identified in each part of the plant including roots, leaves, fruits, and seeds, which account for its broad spectrum of uses [2]. To name a few, such compounds include gallic acid, thymol, and bornyl acetate, which are expected to exert anticancer, anti-inflammatory, and autonomic relaxation induction effects, respectively [3-5]. 
Linalool, a terpene alcohol found in coriander, has been reported to be the main constituent that is responsible for some therapeutic values of coriander as it possesses neuroprotective, anxiolytic, anticonvulsant, and analgesic effects [6-9].

It is believed that every part of the plant possesses different nutritional and medicinal values; thus, it was traditionally consumed in diverse areas. Notably, coriander was used in India for relieving gastrointestinal discomfort, respiratory, and urinary complaints; additionally, in some areas of Pakistan, the whole plant of coriander has folk medicinal uses to treat flatulence, dysentery, diarrhea, and vomiting [10,11]. On the other hand, with its distinctive scent and flavor, coriander is often added to food in the culinary industry as a seasoning and a preservative agent; it can be used in the form of leaves and seeds, ground, or as a whole [12]. Furthermore, the powdered fruit of C. sativum has been used as a flavoring agent to mask the taste of some foods such as fish, meat, and baking recipes [13].

According to the World Health Organization [14] (WHO, 2019), the major cause of mortality worldwide is cardiovascular diseases (CVDs). CVDs are a group of heart and blood vessel disorders including coronary and peripheral artery diseases, rheumatic, cerebrovascular, and congenital heart disease, in addition to deep vein thrombosis and pulmonary embolism [15]. Despite possessing various health benefits which have been reported in many research and review papers [16-18], the cardioprotective effects of coriander have never been summarized in terms of the anti-atherogenic, antihypertensive, antiarrhythmic, and hypolipidemic effects [19]. Phytochemicals present in C. sativum, such as flavonoids, phenolic acids, phytosterols, and terpenes, have significant potential in cardiovascular health and have demonstrated an angiotensin-converting enzyme (ACE)-inhibiting potency, cardioprotective, antihyperlipidemic, and cardiometabolic disorder-inhibiting properties [20-23]. Therefore, the phytochemical constituents of C. sativum were reviewed and summarized in light of their presence in their respective extracts and connected to the biological activities shown. Moreover, this review also aims to further evaluate, summarize, and discuss the cardiovascular effects of coriander extracts in all contexts of in vitro, in vivo, and clinical studies that were performed on this herb.

\subsection{Botanical Description and Taxonomy}

C. sativum belongs to the Apiaceae (Umbelliferae) family, which is herbaceous and grows annually, with a height of 20-70 cm (Table 1). C. sativum is known as "coriander" or "Chinese parsley" in English; "cilantro" in Spanish; "kusthumbari" or "dhanya" in Sanskrit; "dhane" in Bengali; "pak chee" in Thailand; and "Yánsuī", "Yán qiàn", "Hú suī", or "Xiāngcài" in Chinese [1,2,24]. It is thought to have originated in the regions of the Middle East and the Mediterranean, where its growth may have broadened to China, Europe, India, Africa, and Asia; nevertheless, several authors have considered coriander as a weed in cereals, and its origin is still not clear [25]. The leaves are green with a variable lanceolate shape and glabrous surfaces, while the flowers are white or pink in umbels with asymmetrical shapes (Figures 1 and 2) [2,18]. Meanwhile, the seeds are dry schizocarps with two mericarps with oval-shaped globules. Furthermore, the stems of C. sativum are pale green with hollow branches and a glabrous surface [24].

Table 1. The taxonomical classification of C. sativum is as follows.

\begin{tabular}{cc}
\hline Scientific Name: & Coriandrum sativum \\
\hline Common names: & Coriander, Chinese Parsley, cilantro, kusthumbari, dhanya, dhane, \\
pak chee, yuan sui, hu sui \\
Kingdom: & Plantae \\
Subkingdom: & Tracheobionta \\
Superdivision: & Spermatophyta \\
Division: & Magnoliophyta \\
Class: & Magnoliopsida \\
\hline
\end{tabular}


Table 1. Cont.

\begin{tabular}{cc}
\hline Scientific Name: & Coriandrum sativum \\
\hline Subclass: & Rosidae \\
Order: & Apiales \\
Family: & Apiaceae/Umbelliferae \\
Genus: & Coriandrum L. \\
Species: & Coriandrum sativum L. \\
\hline
\end{tabular}

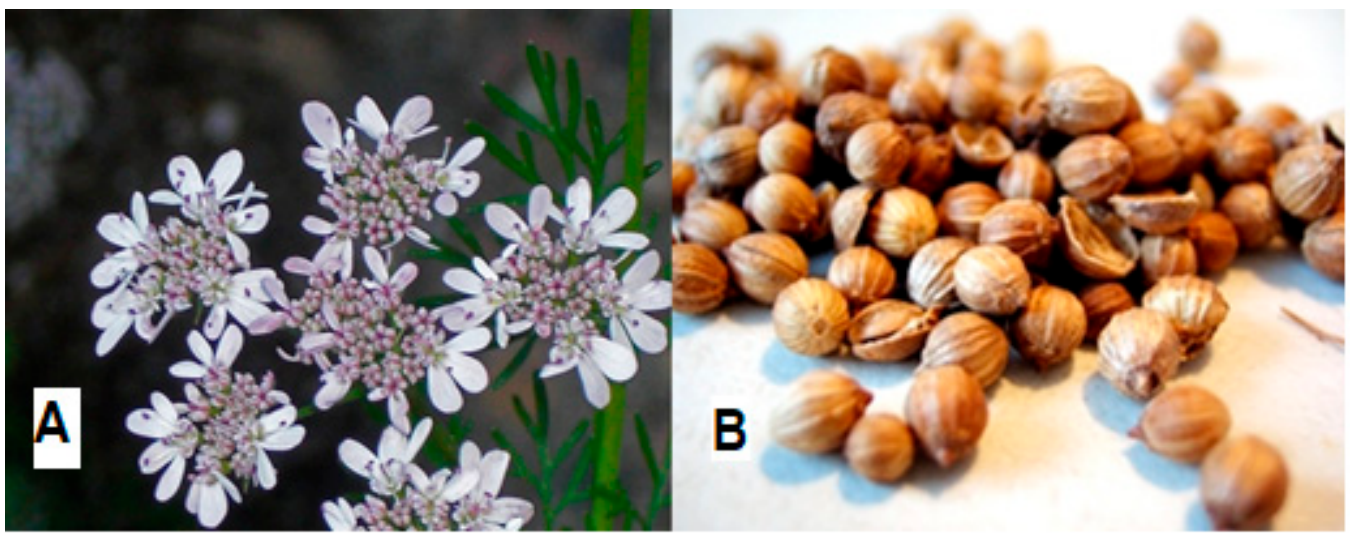

Figure 1. (A) C. satioum flowers (by Andrey Zharkikh). (B) C. satioum half and whole seeds (by ZoyaChubby). From North Carolina Extension Gardner: Plant toolbox. (https:/ / plants.ces.ncsu.edu/ plants/coriandrum-sativum/, accessed on 20 December 2021).

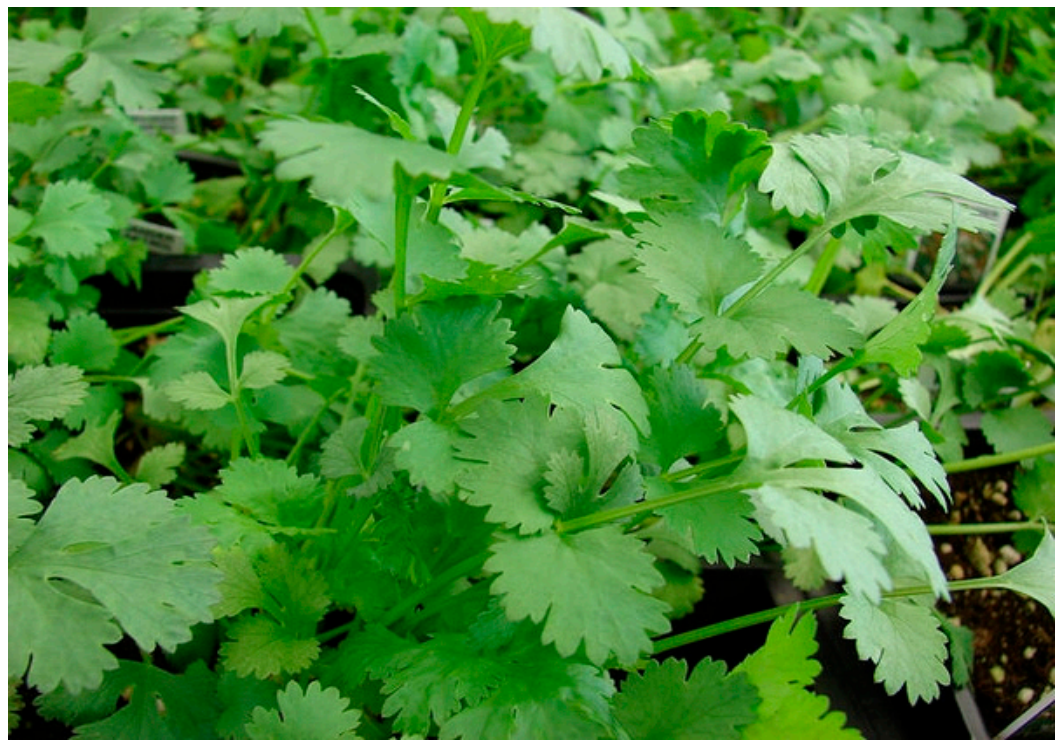

Figure 2. The leaves of Coriandrum sativum (by Forest and Kim Starr). From North Carolina Extension Gardner: Plant toolbox. (https:/ / plants.ces.ncsu.edu/plants/coriandrum-sativum/, accessed on 20 December 2021).

\subsection{Ethnomedicinal Uses}

C. sativum was used as one of the earliest spices by humans. Traditionally, C. sativum seeds were consumed to relieve pain, rheumatoid arthritis, and inflammation [26], whereas the decoction of coriander was believed to treat mouth ulcers and eye redness [27]. The seeds have been prescribed to relieve gastrointestinal disorders such as flatulence, diarrhea, indigestion, and nausea [28]. Coriander is believed to exert these actions by stimulating the liver to increase the secretion of bile and other digestive enzymes which escalate the action of the digestive system, hence shortening the time of food passage through the 
gastrointestinal tract [29]. In countries such as Saudi Arabia, Jordan, and Morocco, coriander was also known to lower blood glucose levels [30-32], have antimicrobial properties against food-borne pathogens, such as Salmonella, in addition to aphrodisiac and analgesic power [33]. Furthermore, coriander has been used traditionally in Turkey and India to relieve indigestion [34]; increase water excretion; and prevent seizures, anxiety, and sleeplessness $[35,36]$. Moreover, it has been documented of C. sativum in Morocco being used traditionally in the treatment of diabetes, indigestion, flatulence, insomnia, renal disorders, loss of appetite, and as a diuretic [37]. Detailed traditional uses of C. sativum are presented in Table 2.

Table 2. Traditional uses of C. sativum in different countries.

\begin{tabular}{|c|c|c|c|}
\hline Traditional Uses & Area & Plant Parts Used & Reference \\
\hline Rheumatoid arthritis, inflammation, and joint pain & India & $\begin{array}{l}\text { Seeds/seeds aqueous } \\
\text { extract }\end{array}$ & {$[26,38,39]$} \\
\hline For measles, diabetes, aerophagy, gastroenteritis & China & The whole plant parts & \multirow{3}{*}{ [40] } \\
\hline Antiviral and neuro-energizer & $\begin{array}{l}\text { Pakistani herbal drugs } \\
\text { (Intellan) }\end{array}$ & Aerial parts of the plant & \\
\hline Some liver diseases & - & $\begin{array}{l}\text { Aqueous extract of the } \\
\text { roasted seeds }\end{array}$ & \\
\hline $\begin{array}{l}\text { Carminative, diuretic, dyspeptic complaints, loss of } \\
\text { appetite, convulsion, insomnia, and anxiety and in } \\
\text { medical purposes }\end{array}$ & Iranian traditional medicine & $\begin{array}{l}\text { Powdered seeds or dry } \\
\text { extract }\end{array}$ & [38] \\
\hline $\begin{array}{l}\text { Diaphoretic, diuretic, carminative, and stimulant } \\
\text { activity }\end{array}$ & Iranian traditional medicine & The whole plant parts & {$[37,41]$} \\
\hline Diuretic and for some renal diseases & Morocco & $\begin{array}{l}\text { Oral administration of } \\
\text { plant parts }\end{array}$ & [42] \\
\hline Mouth ulcer and eye redness & - & leaves decoction & [27] \\
\hline $\begin{array}{c}\text { Grounded as an } \\
\text { ingredient of curry powder and gingerbread, also a } \\
\text { component of liquesces and spirits. Aromatic } \\
\text { ingredient of tobacco and perfumes. } \\
\text { In Unani medicine to quench thirst and } \\
\text { for melancholia. }\end{array}$ & India & $\begin{array}{l}\text { Seeds and aqueous } \\
\text { infusion of leaves }\end{array}$ & [39] \\
\hline $\begin{array}{c}\text { Stimulant and carminative; stomachic, antibilious, } \\
\text { digestive stimulant }\end{array}$ & India & Leaves & [29] \\
\hline Lower blood glucose levels & $\begin{array}{l}\text { Saudi Arabia, Jordan, } \\
\text { Morocco }\end{array}$ & $\begin{array}{l}\text { Fruits, decoction of leaves } \\
\text { and seeds }\end{array}$ & [30-32] \\
\hline Aphrodisiac, analgesic, antimicrobial properties & - & The volatile oil & [33] \\
\hline Appetizer, Digestive, Carminative & Turkey & Infusion of the seeds & [34] \\
\hline For anxiety, sedative and muscle relaxant effect & - & The aqueous extract & {$[35,36]$} \\
\hline $\begin{array}{l}\text { Treats Influenza, bad breath, unpleasant odor } \\
\text { from genitalia }\end{array}$ & Traditional Chinese Medicine & Seeds & \multirow{3}{*}{ [43] } \\
\hline Against worm and to treat rheumatism & The European pharmacopeia & Fruits & \\
\hline $\begin{array}{l}\text { Stimulates gastric secretion, treats gastric ulcers and } \\
\text { mouth infections }\end{array}$ & Asian region & Essential oils & \\
\hline
\end{tabular}

\subsection{Phytochemistry}

Recent studies revealed that different kinds of alkaloids, essential oils, fatty acids, flavonoids, phenolics, reducing sugars, sterols, tannins, and terpenoids were extracted from C. sativum [16,44]. In particular, the leaves were reported to have an abundant concentration of folates, ascorbic acid, gallic acid, caffeic acid, ferulic acid, and chlorogenic acid. 
Additionally, the investigation of the water-soluble components of $C$. sativum seeds showed the presence of 33 compounds, including monoterpenoid, monoterpenoid glycosides and glucosides, and aromatic compound glycosides such as norcarotenoid glucoside [45]. In the vegetative part of the C. sativum, different phenolics and flavonoids were detected in significantly high concentrations, such as quercetin diverse glycosides $(405.36-3296.16 \mathrm{mg} / \mathrm{kg})$, kaempferol 3-O-rutinoside $(320.86 \mathrm{mg} / \mathrm{kg})$, in addition to ferulic acid glucoside and $p$ coumaroylquinic acid [46]. Another study of the polyphenolic contents of coriander grass showed that a $40 \%$ ethanol extract contains many flavonoids $(0.13 \%$ to $10.71 \%)$, coumarins (1.4\% to $6.83 \%$ ), and phenolcarboxylic acids (7.24\% to $13.51 \%)$ [47]. Anthocyanin was also characterized in coriander leaves, and the concentration was found to be influenced by salicylic acid, nitrogen, phosphorus, potassium, and zinc fertilizers [48]. Figure 3 and Table 3 present the different phytochemical structure classes of C. satioum.<smiles>C=CC(C)(O)CCC=C(C)C</smiles>

Linalool<smiles>C=CC(C)(CCC=C(C)C)OC(C)=O</smiles>

Linalyl Acetate<smiles>CC(=O)OC/C=C(\C)CCC=C(C)C</smiles>

Geranyl Acetate<smiles>CC12CCC(CC1=O)C2(C)C</smiles>

Camphor<smiles>O=C(O)c1cc(O)c(O)c(O)c1</smiles>

Gallic acid<smiles>O=C(O)/C=C/c1ccc(O)c(O)c1</smiles>

Caffeic acid<smiles>COc1cc(/C=C/C(=O)O)ccc1O</smiles>

Ferulic acid<smiles>O=C(/C=C/c1ccc(O)c(O)c1)O[C@H]1C[C@](O)(C(=O)O)C[C@H](O)[C@H]1O</smiles>

Chlorogenic acid<smiles></smiles>

Kaempferol<smiles>CCCCCCCCCCC/C=C\CCCCC(=O)O</smiles>

Petroselinic acid

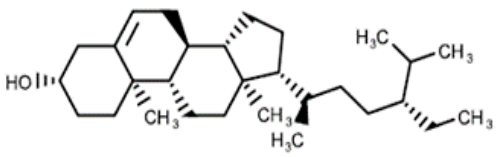

Beta-Sitosterol

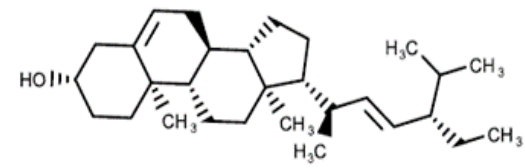

Stigmastero

Figure 3. Phytochemical molecular structures extracted from C. sativum, such as terpenes, phenolic acids, flavonoids, fatty acids, and phytosterols.

These constituents of $C$. sativum were extracted by different methods, including solvent extraction such as n-hexane, water, and methanol, in addition to supercritical gases, microwave-assisted extraction, sonication, and hydrodistillation [20,49-54]. Essential oils (EOs) and fatty oils were the most significant components in the fruit, with a content of 0.03-2.6\% and 9.9-27.7\%, respectively [55]. Different EO chemotypes were detected in coriander seeds, including ketones, aliphatic aldehydes, aliphatic hydrocarbon, aliphatic alcohols, esters, monoterpene hydrocarbons, monoterpene oxides, monoterpene alcohols, monoterpene esters, and sesquiterpenes, with linalool as the main monoterpene alcohol extracted in high quantities [56]. The highest percentage of EO that has been yielded from coriander seeds was cultivated in Tunisia with a linalool content of $87.54 \%$ [57], while 73.1\%, $40.9-79.9 \%, 37.65 \%$, and $69.60 \%$ of linalool was extracted from C. sativum from Algeria, Iran, Bangladesh, and Pakistan, respectively [58-60]. 
EOs are obtainable by extracting different parts of the plant using hydrodistillation extraction [10], subcritical water, Soxhlet apparatus [61], solvent extraction, steam distillation, and supercritical $\mathrm{CO}_{2}$ methods [62]. However, the $\mathrm{EO}$ content is variable among different parts of the plant, which could be due to the different origins of cultivated varieties, climate and geographical conditions $[10,63]$, the area and season of cultivation, the degree of plant maturation, and genotypes of the species. In particular, 2-dodecenal was found as the main volatile EO in the root and stalk, while 1-ethenyl-cyclododecanol was the highest volatile component in the leaves of $C$. sativum [64]. Furthermore, different percentages, components, and immunotoxicity were identified in oils extracted from the leaves than the stems' EO extracts of the Korean C. sativum [65]. In addition, the essential oil yields and efficiencies of commercial coriander fruits from different countries were extracted and found to be different according to the geographical area [66]. The relationship between some environmental conditions in Argentina and the essential oil composition of two coriander landraces (European and Argentinean) has been studied [67]. It has also been found that genotypic and phenotypic variations contributed to the variety of essential oils' concentrations, in addition to the interaction from other environmental conditions, such as fertilizers, weediness, and soil degradation. Likewise, the phenolic contents of the two C. sativum varieties, vulgare and microcarpum, were found to be similar but with different concentrations of the main phenolic compounds, namely quercetin-3-b-D glucoside and quercetin-3-O-glucuronide [68]. On top of that, the average EO yields for vulgare fruits $(0.1 \%$ to $0.5 \%)$ are lower than that of the microcarpum (0.8-2.1\%) [16]. Details of the total phytochemical constituents of $C$. sativum are presented in Table 3 .

Table 3. Main phytochemical constituents of C. sativum classified according to their chemical class, including the plant part that was extracted and the extraction method.

\begin{tabular}{|c|c|c|c|c|}
\hline Phytochemical Components & $\begin{array}{l}\text { Chemical } \\
\text { Class }\end{array}$ & Plant Part & Extraction Solvent/Method & Reference \\
\hline $\begin{array}{c}\text { Ferulic acid, Gallic acid, and } \\
\text { Caffeic acid }\end{array}$ & Phenolic acids & \multirow{4}{*}{ Above-ground parts } & \multirow{4}{*}{$\begin{array}{l}\text { Ether, ethyl acetate, butanol, and } \\
\text { 2-ethyl acetate extracts }\end{array}$} & \multirow{4}{*}{ [47] } \\
\hline Salicylic acid & $\begin{array}{l}\text { Benzoic acid } \\
\text { derivative }\end{array}$ & & & \\
\hline $\begin{array}{l}\text { Esculetin, Esculin, Scopoletin } \\
\text { 4-Hydroxycoumarin, } \\
\text { Umbelliferone, and Dicoumarin }\end{array}$ & Coumarins & & & \\
\hline $\begin{array}{l}\text { Hyperoside, rutin, hesperidin, } \\
\text { vicenin, diosmin, luteolin, } \\
\text { apigenin, orientine, } \\
\text { dihydroquercetin, catechin, and } \\
\text { arbutin }\end{array}$ & Flavonoids & & & \\
\hline$\beta$-carotene and total carotenoids & Carotenoids & $\begin{array}{l}\text { Leaves at mature and } \\
\text { young plant stage, } \\
\text { fresh and dry seeds }\end{array}$ & $\begin{array}{l}\text { Ice-cold acetone was then } \\
\text { partitioned against petroleum } \\
\text { ether. }\end{array}$ & [69] \\
\hline $\begin{array}{c}\alpha-, \beta-, \gamma-\delta \text {-tocopherols, and } \alpha-, \\
\gamma \text {-tocotrienols }\end{array}$ & Tocols & \multirow[b]{2}{*}{$\begin{array}{l}\text { Whole fruit, pericarp, } \\
\text { and seeds }\end{array}$} & Extracted with $n$-hexane & \\
\hline $\begin{array}{l}\text { Petroselinic acid, linoleic acid, } \\
\text { palmitic acid, and oleic acid }\end{array}$ & Fatty acids & & $\begin{array}{l}\text { Boiled in water, then grounded } \\
\text { using a mixture of } \\
\text { chloroform/methanol/hexane } \\
\text { and finally separated by } \\
\text { thin-layer chromatography }\end{array}$ & {$[70]$} \\
\hline $\begin{array}{c}\text { Stigmasterol, } \beta \text {-sitosterol, } \\
\delta \text {-stigmasterol }\end{array}$ & Sterols & \multirow{2}{*}{$\begin{array}{l}\text { Seed and pericarp of } \\
\text { coriander fruit }\end{array}$} & $\begin{array}{l}\text { Extracted with } n \text {-hexane in a } \\
\text { Soxhlet apparatus }\end{array}$ & \multirow{2}{*}[71]{} \\
\hline Linalool, camphor, and geraniol & Essential oils & & $\begin{array}{l}\text { Hydrodistillation followed by } \\
\text { extraction with 2-methylbutane }\end{array}$ & \\
\hline
\end{tabular}


Different studies involved the characterization of C. sativum phytochemicals in the extracts that were employed in bioactivity determination. However, very few studies involved the bioactivity-guided isolation of a specific compound that is responsible for that pharmacological action. Quercetin-rich aqueous ethanolic extract was found beneficial in $\alpha$-amylase and $\alpha$-glucosidase inhibition and thus has a potential antidiabetic effect [72]. The extract also contained some other flavonoid compounds such as vanillic acid, caffeic acid, and p-coumaric acid, whereas the total phenolic content was $2.68 \pm 0.07 \mathrm{mg} \mathrm{GAE} / \mathrm{g}$ DW. Lipase inhibition activity for $1 \mathrm{mg} / \mathrm{mL}$ of aqueous ethanol was $55.76 \pm 1.40 \%$ which indicates a significantly strong anti-obesity property. In the same study, the angiotensinconverting enzyme was inhibited by coriander extracts to $70.66 \pm 2.34 \%$ which shows that the polyphenolic-rich extract can be beneficial for hypertension in vitro. Moreover, the diabetic nephropathy prevention and hypolipidemic activities were illustrated in the petroleum ether extract of C. sativum seeds that are rich in linalool, ascorbyl palmitate, and petroselinic acid [73]. The saturation of hexokinase enzymes due to diabetes leads to the formation of advanced glycation end products (AGEs), which when interacting with their receptors cause vascular aging and renal damage [74]. From the above-mentioned study, it was found that linalool in addition to other terpenes and fatty acids has the potential to bind with the RAGE receptor and subsequently block AGEs' damaging action. In a different study, the Eos' major components of $C$. sativum were linalool, $\gamma$-terpinene, and $\alpha$-pinene with prominent activities against diabetes, microbial infections, and acetylcholinesterase enzyme [75]. Other activities such as hypotensive [20] and neuroprotective ones [76] were detected in flavonoids- and isocoumarin glycosides-containing fractions of C. sativum, respectively. The isocoumarin glycosides cilantroside A and B, in addition to the phenolic glycosides daphnin and benzyl-O- $\beta$-d-glucoside, have been found to stimulate nerve growth factor as the main neurotrophic factor which is related to nerve growth, maintenance, and neuronal survival. Moreover, the aglycones of the isocoumarins showed anti-inflammatory effects in addition to more significant neurotrophic properties than their glycosides. Figure 4 indicates the details on studies performed on $C$. sativum with the characterization or isolation of the phytochemicals in the respective extract/fraction.

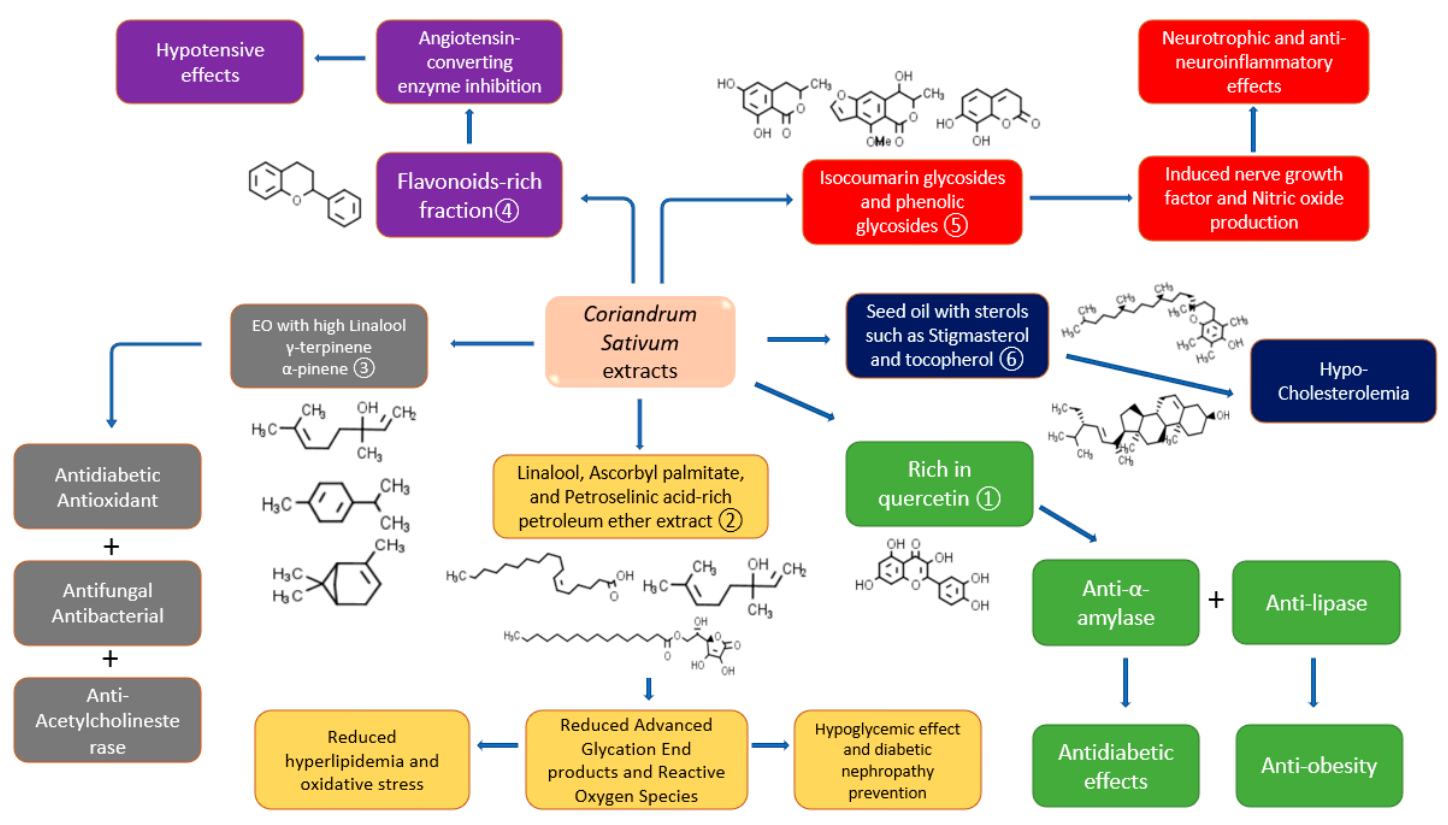

Figure 4. The role of $C$. sativum phytochemicals in some of its biological activities from different studies (1) Suttisansanee, Thiyajai, Chalermchaiwat, Wongwathanarat, Pruesapan, Charoenkiatkul and Temviriyanukul [72], (2) Kajal and Singh [73], (3) Hajlaoui, Arraouadi, Noumi, Aouadi, Adnan, Khan, Kadri and Snoussi [75], (4) Hajlaoui, Arraouadi, Noumi, Aouadi, Adnan, Khan, Kadri and Snoussi [75], (5) Cha, Yoon, Kim, Kim and Lee [76], and (6) Ramadan, et al. [77]. 


\section{Results}

From previous studies, C. sativum has demonstrated its cardioprotective efficacies (refer to Graphical Abstract). These include its effect as an antioxidant, antihypertensive, anti-atherogenic, antiarrhythmic, as well as the improvement of other factors that may lead to CVDs, such as increased lipid profile and cardiac biomarkers or enzymes. From the PRISMA flow diagram, Figure 3 demonstrates the search strategy that has been used and its results; a total of 3008 studies were screened and 13 were excluded from this review as duplicate records before the screening. A total of 2977 studies were further excluded for not meeting the determined inclusion criteria, thus leaving only 18 studies to be retrieved and included in this review. Twelve in vivo, two in vitro, and two clinical studies in addition to two mixed in vivo and in vitro studies were retrieved. The results of the studies included in this review, plant parts extracted, extraction method, dose employed, phytochemicals characterized, and isolation method are summarized in Table 4.

Table 4. Cardiovascular potential of $C$. sativum from previous studies with details about the plant part used, extraction method, dosage em-ployed, phaytochemicals characterized, and isolation method.

\begin{tabular}{|c|c|c|c|c|c|c|c|}
\hline Plant Part & $\begin{array}{c}\text { Extraction } \\
\text { Method }\end{array}$ & $\begin{array}{c}\text { Dosage } \\
\text { Employed }\end{array}$ & $\begin{array}{c}\text { Phytochemicals } \\
\text { Characterized }\end{array}$ & $\begin{array}{l}\text { Isolation } \\
\text { Method }\end{array}$ & $\begin{array}{l}\text { Experimental } \\
\text { Subject }\end{array}$ & $\begin{array}{c}\text { Cardiovascular } \\
\text { Effects } \\
\text { (Outcome) }\end{array}$ & Reference \\
\hline $\begin{array}{l}\text { Leaves and } \\
\text { stem }\end{array}$ & $\begin{array}{l}\text { Ethanol } \\
\text { extraction }\end{array}$ & $200 \mathrm{mg} / \mathrm{kg}$ & Phenolics, flavonoids & Evaporation & $\begin{array}{l}\text { Wistar albino } \\
\text { rats }\end{array}$ & $\begin{array}{c}\text { Antioxidant, } \\
\text { Hypolipidemic } \\
\text { Normoglycemic }\end{array}$ & $\begin{array}{c}\text { Ananthan, et al. } \\
\text { [78] }\end{array}$ \\
\hline Seeds & $\begin{array}{l}\text { Methanol } \\
\text { extraction }\end{array}$ & $\begin{array}{l}100 \mathrm{mg} / \mathrm{kg}, \\
200 \mathrm{mg} / \mathrm{kg}, \\
300 \mathrm{mg} / \mathrm{kg}\end{array}$ & $\mathrm{N} / \mathrm{D}$ & $\begin{array}{l}\text { Reduced } \\
\text { pressure }\end{array}$ & $\begin{array}{l}\text { Adult male } \\
\text { Wistar rats }\end{array}$ & $\begin{array}{c}\text { Decrease cardiac } \\
\text { damage that } \\
\text { causes } \\
\text { myocardial } \\
\text { infarction }\end{array}$ & $\begin{array}{l}\text { Patel, Desai, } \\
\text { Gandhi, } \\
\text { Devkar and Ra- } \\
\text { machandran } \\
\text { [49] }\end{array}$ \\
\hline Seeds & $\begin{array}{l}\text { Soxhlet } \\
\text { extraction }\end{array}$ & $250 \mathrm{mg} / \mathrm{kg}$ & $\mathrm{N} / \mathrm{D}$ & $\begin{array}{l}\text { Reduced } \\
\text { pressure }\end{array}$ & $\begin{array}{l}\text { Male albino } \\
\text { rabbits }\end{array}$ & Hypolipidemic & $\begin{array}{c}\text { Sharma, et al. } \\
\text { [79] }\end{array}$ \\
\hline $\begin{array}{l}\text { Market- } \\
\text { procured } \\
\text { coriander } \\
\text { powder } \\
\text { suspended } \\
\text { in water }\end{array}$ & - & $1 \mathrm{~g} / \mathrm{kg}$ & $\mathrm{N} / \mathrm{D}$ & - & $\begin{array}{l}\text { Male Wistar } \\
\text { rats }\end{array}$ & Hypolipidemic & Lal, et al. [80] \\
\hline $\begin{array}{c}\text { Seed } \\
\text { powder }\end{array}$ & - & $2 \mathrm{~g}$ per day & $\mathrm{N} / \mathrm{D}$ & - & $\begin{array}{c}\text { Human } \\
\text { individuals }\end{array}$ & $\begin{array}{c}\text { Lower elevated } \\
\text { blood pressure, } \\
\text { Hypocholes- } \\
\text { terolemic }\end{array}$ & Zeb, et al. [81] \\
\hline $\begin{array}{c}\text { Market- } \\
\text { procured } \\
\text { seeds, } \\
\text { powdered }\end{array}$ & - & 5 g per day & $\mathrm{N} / \mathrm{D}$ & - & $\begin{array}{l}\text { Type } 2 \\
\text { diabetic } \\
\text { patients }\end{array}$ & $\begin{array}{l}\text { Hypolipidemic, } \\
\text { antioxidant }\end{array}$ & $\begin{array}{l}\text { Rajeshwari, } \\
\text { et al. [82] }\end{array}$ \\
\hline Seeds & $\begin{array}{l}\text { Aqueous } \\
\text { extraction }\end{array}$ & $200 \mathrm{mg} / \mathrm{kg}$ & $\mathrm{N} / \mathrm{D}$ & - & $\begin{array}{l}\text { Meriones } \\
\text { shawi rats }\end{array}$ & $\begin{array}{l}\text { Hypolipidemic } \\
\text { Normo-glycemic } \\
\text { Cardioprotective }\end{array}$ & $\begin{array}{c}\text { Aissaoui, et al. } \\
\text { [83] }\end{array}$ \\
\hline Seeds & Hydrodistillation & $\begin{array}{c}\mathrm{IC}_{50}: 34.8 \pm \\
2.3 \mu \mathrm{g} / \mathrm{mL}\end{array}$ & Linalool & Hydrodistillation & $\begin{array}{l}\text { In vitro } \\
\text { study }\end{array}$ & $\begin{array}{c}\text { Antihypertensive, } \\
\text { Antioxidant }\end{array}$ & $\begin{array}{l}\text { Chaudhary, } \\
\text { et al. [84] }\end{array}$ \\
\hline Seeds & $\begin{array}{l}\text { Maceration } \\
\text { in methanol }\end{array}$ & $183 \mathrm{mg} / \mathrm{kg}$ & $\mathrm{N} / \mathrm{D}$ & - & Rats & Cardioprotective & $\begin{array}{c}\text { Afsheen, et al. } \\
\text { [85] }\end{array}$ \\
\hline Seeds & $\begin{array}{l}\text { Homogenized } \\
\text { seeds }\end{array}$ & $10 \%$ of diet & $\mathrm{N} / \mathrm{D}$ & - & $\begin{array}{l}\text { Sprague- } \\
\text { Dawley } \\
\text { rats }\end{array}$ & Hypolipidemic & $\begin{array}{c}\text { Dhanapakiam, } \\
\text { et al. [86] }\end{array}$ \\
\hline Seeds & $\begin{array}{l}\text { Aqueous } \\
\text { extraction }\end{array}$ & $1 \mathrm{~g} / \mathrm{kg}$ & $\mathrm{N} / \mathrm{D}$ & - & $\begin{array}{l}\text { Wistar albino } \\
\text { rats }\end{array}$ & $\begin{array}{c}\text { Cardioprotective, } \\
\text { Hypolipidemic, } \\
\text { Antioxidant, } \\
\text { Improved left } \\
\text { ventricle } \\
\text { functions }\end{array}$ & $\begin{array}{c}\text { Dhyani, et al. } \\
\text { [87] }\end{array}$ \\
\hline
\end{tabular}


Table 4. Cont.

\begin{tabular}{|c|c|c|c|c|c|c|c|}
\hline Plant Part & $\begin{array}{l}\text { Extraction } \\
\text { Method }\end{array}$ & $\begin{array}{c}\text { Dosage } \\
\text { Employed }\end{array}$ & $\begin{array}{l}\text { Phytochemicals } \\
\text { Characterized }\end{array}$ & $\begin{array}{l}\text { Isolation } \\
\text { Method }\end{array}$ & $\begin{array}{l}\text { Experimental } \\
\text { Subject }\end{array}$ & $\begin{array}{c}\text { Cardiovascular } \\
\text { Effects } \\
\text { (Outcome) }\end{array}$ & Reference \\
\hline Leaves & $\begin{array}{l}\text { Soxhlet } \\
\text { extraction } \\
\text { with } \\
\text { multiple } \\
\text { solvents }\end{array}$ & $\begin{array}{l}\mathrm{IC}_{50}: 28.91 \pm \\
13.42 \mu \mathrm{g} / \mathrm{mL}\end{array}$ & $\begin{array}{l}\text { Pinocembrin, Apigenin, } \\
\text { pseudobaptigenin, } \\
\text { galangin-5-methyl ether, } \\
\text { quercetin, baicalein, } \\
\text { kaempferol, } \\
\text { pinobanksin-glycosides, } \\
\text { rutin, isorhamnetin, } \\
\text { daidzein, luteolin, } \\
\text { pectolinarigenin }\end{array}$ & $\begin{array}{l}\text { LC-ESI- } \\
\mathrm{MS} / \mathrm{MS}\end{array}$ & $\begin{array}{l}\text { In vitro } \\
\text { study }\end{array}$ & Antihypertensive & $\begin{array}{l}\text { Hussain, Jahan, } \\
\text { Rahman, } \\
\text { Sultana and } \\
\text { Jamil [20] }\end{array}$ \\
\hline Seeds & $\begin{array}{l}\text { Solvent } \\
\text { extraction }\end{array}$ & $\begin{array}{l}\text { Addition of } \\
100 \mathrm{~g} \text { to diet }\end{array}$ & $\begin{array}{c}\text { Stigmasterol, Lanosterol, } \\
\beta \text {-Sitosterol, } \\
\text { D }^{5} \text { Avenasterol, Sitostanol, } \\
\text { D }^{7} \text { stigmastenol, D7 } \\
\text { Avenasterol, Tocopherols }\end{array}$ & $\begin{array}{l}\text { Gas-liquid } \\
\text { chromatog- } \\
\text { raphy }\end{array}$ & $\begin{array}{l}\text { Male albino } \\
\text { rats }\end{array}$ & $\begin{array}{c}\text { Hypocholesterolemic } \\
\text { effect }\end{array}$ & $\begin{array}{l}\text { Ramadan, } \\
\text { Amer and } \\
\text { Awad [77] }\end{array}$ \\
\hline Seeds & $\begin{array}{l}\text { Homogenized } \\
\text { seeds }\end{array}$ & $10 \%$ of diet & N/D & - & $\begin{array}{c}\text { Female } \\
\text { albino rats }\end{array}$ & Hypolipidemic & $\begin{array}{l}\text { Chithra and } \\
\text { Leelamma [88] }\end{array}$ \\
\hline Seeds & $\begin{array}{c}\text { Water } \\
\text { extraction }\end{array}$ & $300 \mathrm{mg} / \mathrm{kg}$ & N/D & - & $\begin{array}{l}\text { Male albino } \\
\text { rats }\end{array}$ & Antiarrhythmic & $\begin{array}{l}\text { Rehman, Jahan, } \\
\text { Khalil ul, Khan } \\
\text { and Zafar [51] }\end{array}$ \\
\hline Seeds & $\begin{array}{l}\text { Maceration } \\
\text { with Aque- } \\
\text { ous/Methanol }\end{array}$ & $200 \mathrm{mg} / \mathrm{kg}$ & $\mathrm{N} / \mathrm{D}$ & - & $\begin{array}{l}\text { In vitro and } \\
\text { in vivo study } \\
\text { on } \\
\text { Sprague- } \\
\text { Dawley } \\
\text { rats }\end{array}$ & $\begin{array}{l}\text { Antioxidant, } \\
\text { Hypocholes- } \\
\text { terolemic } \\
\text { Anti-atherogenic }\end{array}$ & Patel, et al. [89] \\
\hline Fruit & $\begin{array}{l}\text { Maceration } \\
\text { with Aque- } \\
\text { ous/Methanol }\end{array}$ & $\begin{array}{l}1-30 \mathrm{mg} / \mathrm{mL} \\
\text { as } \\
\text { hypotensive } \\
1-10 \mathrm{mg} / \mathrm{kg} \\
\text { as diuretic }\end{array}$ & $\mathrm{N} / \mathrm{D}$ & $\begin{array}{l}\text { Organic } \\
\text { fractionation } \\
\text { of the crude } \\
\text { extract }\end{array}$ & $\begin{array}{l}\text { In vivo and } \\
\text { in vitro } \\
\text { study }\end{array}$ & $\begin{array}{c}\text { Anti- } \\
\text { hypertensive, } \\
\text { Diuretic }\end{array}$ & $\begin{array}{c}\text { Jabeen, Bashir, } \\
\text { Lyoussi and } \\
\text { Gilani [50] }\end{array}$ \\
\hline Leaves & $\begin{array}{l}\text { Maceration } \\
\text { with } \\
\text { Methanol }\end{array}$ & $100 \mathrm{mg} / \mathrm{kg}$ & $\mathrm{N} / \mathrm{D}$ & - & Rabbits & Hypolipidemic & $\begin{array}{c}\text { Kousar, et al. } \\
\text { [90] }\end{array}$ \\
\hline
\end{tabular}

\section{Discussion}

\subsection{Hypolipidemic Activity}

Crude C. satioum extract has been shown to lower the levels of triacylglycerol (TCA) and total cholesterol (TC), indicating its potential in decreasing blood lipid profile in rats $[77,79,80,82,83,86-88,90]$. Bioactive sterols, which contain mono- and polyunsaturated fatty acids, such as stigmasterols and sitosterols, and polar lipids, are present in coriander extract in high amounts [77]. In addition, the presence of antioxidants, such as tocopherols and phenolics, protects the unsaturated fatty acids from peroxidation [91]. Saturated fatty acids likely elevate the low-density lipoprotein cholesterol (LDL-C) levels, while unsaturated fatty acids, including monounsaturated and polyunsaturated fatty acids (PUFA), reduce LDL-C levels [92]. The higher intake of PUFA-containing oils in food helps in incorporating more unsaturated fatty acids in plasma lipoproteins, which improves their particle size and subclass distribution more than when it involves a higher content of cholesterol particles due to the fact that the fatty esters such as PUFA are bigger in size [93]. Additionally, cholesterol as a rigid fat will be incorporated more as a cell membrane component instead of circulating in blood since the fluidity of unsaturated acids in membranes must be balanced with rigid fats [94]. Moreover, phytochemical components such as flavonoids and polyphenols can also be responsible for the hypolipidemic property of coriander, whereby the flavonoids are responsible for reducing FAS proteins which are involved in energy metabolism. The inhibition of the expression of FAS in the liver by stimulating AMPK activity in hepatocyte cells via the liver kinase B1 pathway may thereby reduce fatty acid synthesis in the liver and subsequently, fat accumulation [95]. 
Another potential hypolipidemic mechanism for coriander seeds proposed by Chithra and Leelamma [88] may involve a significant increase in the 3-hydroxy-3-methylglutaryl coenzyme A reductase (HMG-CoA) activity which is a key enzyme in the biosynthesis of cholesterol. Since liver cholesterol was significantly reduced in rats administered coriander, it was most likely because the rate of its degradation to bile acids was more than its rate of synthesis. Other than that, Sharma, Sharma, Jasuja and Joshi [79] found an increase in the excretion of cholesterol and phospholipids in the fecal matter of rabbits that were administered C. sativum seed extract. Generally, plant sterols and stanols reduce intestinal absorption of cholesterol, increase neutral fecal sterol excretion, and prevent liver cholesterol accumulation; however, they did not cause liver $\mathrm{X}$ receptor target gene induction, such as $A b c g 5, A b c g 8$, or Npc1l1. Thus, phytosterol-induced cholesterol absorption reduction was independent of Abcg5/8 Transporter [96].

In contrast, the reduction of TC levels was attributed to the amount of fibers added to the experimental diet of hypertriglyceridemic rats [88,97], which further increases plasma lecithin cholesterol acyltransferase (LCAT) activity, amplifies the synthesis of hepatic bile acids, thus increasing the cholesterol degradation in the fecal excretion of bile acids and cholesterol, and decreases the LDL liver production. Coriander seed oil is rich in sterols, predominantly stigmasterol and $\beta$-sitosterol, which work preemptively on inhibiting the absorption of dietary cholesterol $[88,98]$. The slight difference between stigmasterol and cholesterol structures allows the former to be incorporated in intestinal micelle to displace cholesterol and subsequently reduces the latter absorption. Furthermore, phytosterols, especially stigmasterol, increase the enzyme activity of HMG-CoA reductase, which suppresses cholesterol absorption and enhances hepatic bile acids synthesis and thus, increases the degradation of cholesterol [99].

\subsection{Antioxidant and Anti-Atherogenic Properties}

Antioxidants play an important role in the promotion of cardiovascular health since oxidative stress that inflicts the myocardium can be associated with the incidence of atherosclerosis, which increases the risk of coronary artery disease $[100,101]$. C. sativum has been demonstrated in many studies to possess a pronounced antioxidant activity, and this is mainly due to the activity of polyphenols, vitamins, and sterol constituents of coriander $[78,89,90]$.

In particular, the antioxidant mechanism that is correlated with the ability of C. sativum phytochemicals is to inhibit scavenger receptor (SRB1) expression, which in turn decreases the number of foam cell formations and subsequently reduces the atherogenic plaques $[79,89]$. Furthermore, the atherosclerosis mechanism involves the accumulation of LDL-C within the walls of arteries, which then develop into a cholesterol plaque. Described as an inflammatory disease, atherosclerosis involves the oxidation processes by reactive oxygen species and lipoxygenases, along with enzymatic changes that occur to the entrapped LDL-C and extracellular matrix (ECM). Those changes increase the generation of adhesion molecules and chemokines from endothelial cells that boost the adhesiveness of monocytes on the cell wall, which also facilitates the infiltration of inflammatory cells into the subendothelial spaces [102,103]. This results in the recruitment of macrophages to scavenge this oxidized LDL (Ox-LDL) via scavenger receptor (SRB1), which is subsequently converted into lipid-laden foam cells [104]. Eventually, these cells undergo apoptotic death in which the apoptotic bodies mimic a fatty streak [105]. Furthermore, this increases the recruitment of macrophages having a similar fate, whereby the buildup of the by-products promotes atherosclerosis [105]. Therefore, coriander extract lowers the development of Ox-LDL in a dose-dependent manner as it has demonstrated the reduction in the number of foam cells due to its potential to prevent the expression of SRB1 [79,89].

Another potential antioxidant mechanism is associated with the high levels of polyphenol in the leaf extract of C. sativum [106,107], which acts as a free radical scavenger, thus preventing oxidative damage to the myocardial tissues [89]. Free radicals are highly reactive; for instance, hydroxyl radicals can cause damage to membrane phospholipids, DNA, 
and proteins, in which the former would result in the formation of peroxyl radicals [77]. Thus, when there are insufficient natural antioxidant components in the body, such as superoxide dismutase (SOD) enzyme and glutathione peroxidase (GSH-px), an oxidative chain reaction may occur [78], resulting in tissue damage [108]. However, it has been reported that this strong antioxidant potential of coriander may also be due to the synergistic effect of the combination of different antioxidant compounds, such as tocopherols and sterols [77].

Plants with green leaves such as coriander produce volatile oils, usually composed of (E)-2-Alkenals, emitted when wounds and stress are applied to them as a defense mechanism. N-pentane extract of C. sativum accounts for $70 \%$ of the components of its essential oil to this kind of green leaf volatiles [109]. It has been suggested that those alkenals attach to Keap 1 proteins through electrophilic modification by the $\alpha, \beta$-unsaturated aldehyde group, resulting in Nrf2 activation. This activation leads to detoxification and ROS neutralization in different in vivo and in vitro assays [110]. Furthermore, umbelliferone is a coumarin derivative that was extracted from C. sativum using methanol [111] and is also found to increase the expression of Nrf2 in addition to CREB, SIRT1, FOXO-3, PPAR- $\gamma$ genes, and proteins. SIRT1 upregulation plays a key role in regulating oxidative defense mechanisms and DNA repair [112] and can be considered one of the pathways in which coriander illustrates its antioxidant and anti-atherogenic effects.

Furthermore, a study by Dhyani, Parveen, Siddiqi, Hussain and Fahim [87] demonstrated the ability of $C$. sativum seed extract to improve the cardiac hemodynamic parameters, namely systolic blood pressure (SBP), diastolic blood pressure (DBP), heart rate (HR), and mean arterial pressure (MAP) in the experimental rats. The reflective response in the case of myocardial ischemic injury is illustrated by a decline in the MAP and an increase in the HR and cardiac contractility, whereby the latter happens due to the activation of baroreceptors, eventually leading to vasoconstriction and hence enhancing the imbalance between the oxygen supply and demand in the cardiac tissues [87]. The coriander extract is expected, as illustrated in the above-mentioned studies, to improve these parameters, and ultimately, the event of MI can be prevented. A cardioprotective effect was also demonstrated for the polyphenol-rich extract of C. sativum due to its antioxidant potential that is associated with preventing myocardial infarction due to myofibrillar injury after the isoproterenol-induction of cardiac damage in male Wister rats [49]. The elevation of the reactive oxygen species is associated with myocardial damage, causing necrosis, apoptosis, or autophagy due to the swelling of mitochondria, which is attributed to the calcium being diverted to it after disruption in its handling between the sarcoplasmic reticulum and myofilament [113].

In addition to the mechanisms above, the histology of the aorta was also studied to determine the effect of $C$. sativum extract on cholesterol deposition in rabbits, showing almost normal histology whereby the aorta and the size of the lumen were restored to almost the normal state, thus proving the anti-atherogenic potential of coriander. In contrast to that, the histological observation of the aorta of cholesterol-fed animals without the extract treatment exhibited atheromatous plaque as compared to the normal-fed group. The lipids deposited in the atherosclerotic lesions are mostly derived from LDL, which can be oxidized by pro-oxidants, resulting in plaques characterized by lipid-laden foam cells within the innermost and middle layers of the aorta [79]. The atherogenic index serves as a crucial prognostic indicator for CVDs such as atherosclerosis [114], which represents the ratio between cholesterol and high-density lipoprotein (HDL) [115]. Increased risk of myocardial infarction is denoted by the atherogenic index of more than five [116]. Moreover, a significant decrease in this ratio by $C$. sativum extract has been reported in a previous study by Sharma, Sharma, Jasuja and Joshi [79] and Aissaoui, Zizi, Israili and Lyoussi [83], indicating another potential of coriander as a functional food to decrease the risk of CVDs. 


\subsection{Antihypertensive Potential}

Another potential cardioprotective effect of $C$. sativum is its antihypertensive property $[20,51]$. This property is attributed to the flavonoid-rich leaves of C. sativum, particularly involving the angiotensin-converting enzyme (ACE) inhibition mechanism that has been illustrated in vitro by Hussain, Jahan, Rahman, Sultana and Jamil [20], whereby its $\mathrm{IC}_{50}$ value was $28.91 \mu \mathrm{g} / \mathrm{mL}$, which is comparable to other plants possessing the same property as the $\mathrm{IC}_{50}$ values of plant extracts that exhibit this enzyme inhibition ranges from 16-310 $\mu \mathrm{g} / \mathrm{mL}$ [117-119]. Flavonoids that have been identified in coriander leaves include quercetin, rutin, apigenin, and luteolin [120-122], which have also been proven to show hypotensive effects individually and in crude extracts in diverse mechanisms [123-126]. The potential mechanism in the management of hypertension through the inhibition of ACE involves the control of the production of nitric oxide (NO) by the regulatory mechanism of the renin-angiotensin-aldosterone system (RAAS) with ACE inhibition as a fundamental regulator of blood pressure [20]. NO is an essential vasodilator in the regulation of blood pressure. ACE binds with the substrate in addition to the zinc ion in the complex, resulting in the polarization of the carbonyl group, thus promoting a nucleophilic attack, which contributes to an elevation in blood pressure [20]. Therefore, some flavonoids, as well as the free hydroxyl groups of flavonoids, inhibit ACE action by chelation with the zinc ion on the active site of ACE [127], which might be due to the formation of hydrogen bridges with amino acids nearby this active site [128-130]. Hence, this demonstrates the cardioprotective effect of coriander extract by the action of this class of polyphenols.

Furthermore, the investigation of the antihypertensive effect of the crude extract of C. sativum in anesthetized rats was shown to induce the relaxation of arterial contractions, thus lowering blood pressure [50]. It has been reported that such an effect occurs due to the combination of the cholinergic and calcium channel blocking effects of coriander bioactive compounds [131]. Additionally, the diuretic effect of $C$. sativum contributes to this antihypertensive activity by increasing the loss of electrolytes in the urine output [132]. Therefore, the findings from those studies potentiate the assumption of the instrumental use of coriander extract in hypertension as a functional food.

\subsection{Antiarrhythmic Activity}

Arrhythmia is one of the CVDs, which can be defined as irregular patterns of heart rate or rhythm that could be either tachycardia or bradycardia [133]. The antiarrhythmic activity of $C$. sativum seed extract has been evaluated in a study by Rehman, Jahan, Khalil ul, Khan and Zafar [51] that resulted in the reduction of pulse rate as well as the normalization of electrocardiogram (ECG) patterns and cardiac biomarker levels, which include lactate dehydrogenase (LDH), creatine kinase-MB fraction (CK-MB), aspartate transaminase (AST), and alanine transaminase (ALT). Rehman, Jahan, Khalil ul, Khan and Zafar [51] found that the anti-tachycardia efficiency of $C$. sativum was comparable with the beta-blocker drug propranolol, but less for the anti-bradycardia effect than that of atropine, whereby the presence of polyphenolic compounds may be responsible for this action. Polyphenols bind with beta-adrenergic receptors for the regulation of heart rate, as well as having a negative chronotropic effect which may slow down myocytes' action potential, thus possibly deterring arrhythmias [107].

\section{Materials and Methods}

Electronic databases that were used for this review were PubMed, Scopus, Google Scholar, preprint platforms, and the Cochrane Database of Systematic Reviews. The articles were gathered from the inception of the database until August 2021. The strategies used for the electronic search are shown in Figure 5 (PRISMA Flow diagram). 


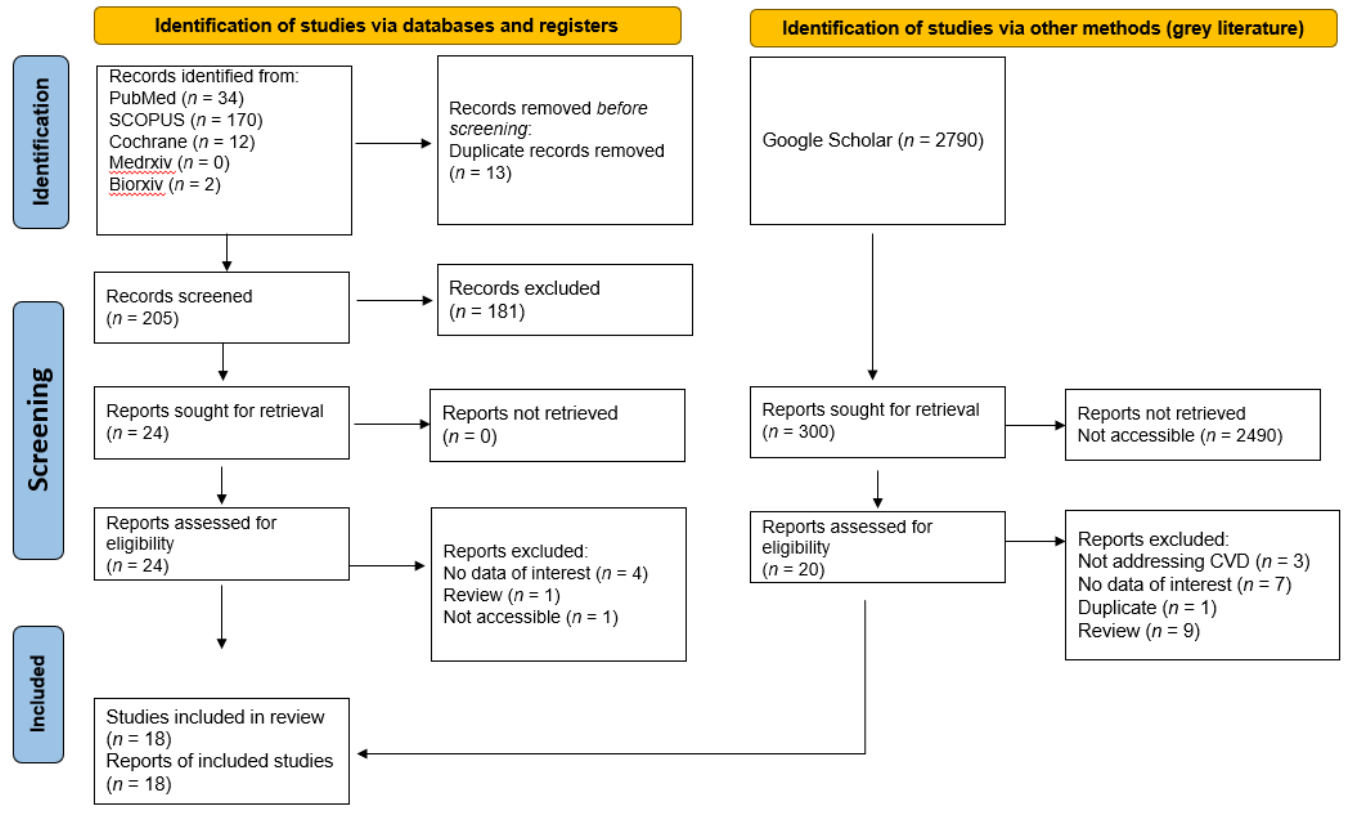

Figure 5. PRISMA Flow Diagram.

The terms used to conduct the search included: "Coriandrum sativum", coriander, cilantro, cardiovascular, hypertensive, blood pressure, atherosclerosis, myocardial, cardiology, cardiac, heart, hyperlipidemia, cholesterol, health benefit, benefit, uses, clinical effect, clinical use, medicine, ethnomedicine, phytotherapy, and ethnobotany. These terms were used in combination with the Boolean operators "AND" and "OR", and the search strategy can be found in Supplementary Table S1. The search terms for Preprint Platform were restricted to "Coriandrum sativum", coriander, and cilantro to limit the search results for the topic of interest.

The eligibility of studies to be included in this review was assessed according to the following inclusion and exclusion criteria:

Inclusion criteria:

1. Articles including research articles, guidelines, monographs, technical papers, conference proceedings;

2. Studies that are reported in the English language only,

3. Treatment of cardiovascular diseases;

4. Human studies, in vivo animal model, and in vitro laboratory studies;

5. There was no limitation imposed on the year of publication of the studies.

Exclusion criteria: Studies that assess other benefits of coriander that do not relate to cardiovascular health, reviews, letters, case studies, conference papers, opinions, reports, or editorial papers.

Screening of publications on studies relevant to coriander that examine its cardioprotective activity was conducted. Relevant literature was retrieved and reviewed in case they were related to the pharmacological properties and therapeutic actions of C. sativum.

\section{Conclusions}

Coriander has been widely used over the past centuries for both culinary and traditional purposes. Although linalool has been identified in C. sativum extract as the main component in the extracted oil, many flavonoids, phenolic acids, and phytosterols were found to be the major groups of phytochemicals that are expected to be accountable for the cardioprotective effects of coriander. In this review, the efficacy of coriander in CVDs has been discussed and evaluated according to the previous studies and reports, in which $C$. sativum is shown to exhibit hypolipidemic, antioxidant, antiatherogenic, antihypertensive, and antiarrhythmic properties in a dose-dependent manner. The included studies in this 
systematic review shed the light on the cardioprotective ability of coriander; however, more in vitro studies are needed to elucidate the mechanism of action of its extracts in cardiovascular diseases. Clinical trials are also warranted for fresh and extracted C. sativum to confirm the results presented in this review in an endeavor to consider it as a functional food and nutraceutical agent that can be consumed for therapeutic and nutritive purposes.

Supplementary Materials: The following supporting information can be downloaded at: Table S1: Table of search terms combination and strategy.

Author Contributions: Conceptualization, L.C.M. and H.P.G.; methodology, N.N.M. and Y.M.A.-W.; formal analysis, N.N.M. and S.M.; investigation, H.H.Z.; data curation, N.N.M. and N.K.; writingoriginal draft preparation, N.N.M. and M.J.L.; writing—review and editing, S.M., S.T. and M.M.R.S.; visualization, S.M. and H.P.G.; supervision, B.H.G., H.P.G. and L.C.M.; project administration, B.H.G., S.T. and H.P.G. All authors have read and agreed to the published version of the manuscript.

Funding: This research work did not receive any external funding.

Institutional Review Board Statement: Not applicable.

Conflicts of Interest: The authors declare no conflict of interest.

\section{References}

1. Prachayasittikul, V.; Prachayasittikul, S.; Ruchirawat, S.; Prachayasittikul, V. Coriander (Coriandrum sativum): A promising functional food toward the well-being. Food Res. Int. 2018, 105, 305-323. [CrossRef] [PubMed]

2. Mandal, S.; Mandal, M. Coriander (Coriandrum sativum L.) essential oil: Chemistry and biological activity. Asian Pac. J. Trop. Biomed. 2015, 5, 421-428. [CrossRef]

3. Riella, K.R.; Marinho, R.R.; Santos, J.S.; Pereira-Filho, R.N.; Cardoso, J.C.; Albuquerque-Junior, R.L.; Thomazzi, S.M. Anti-inflammatory and cicatrizing activities of thymol, a monoterpene of the essential oil from Lippia gracilis, in rodents. J. Ethnopharmacol. 2012, 143, 656-663. [CrossRef] [PubMed]

4. Matsubara, E.; Fukagawa, M.; Okamoto, T.; Ohnuki, K.; Shimizu, K.; Kondo, R. (-)-Bornyl acetate induces autonomic relaxation and reduces arousal level after visual display terminal work without any influences of task performance in low-dose condition. Biomed. Res. 2011, 32, 151-157. [CrossRef]

5. Sun, G.; Zhang, S.; Xie, Y.; Zhang, Z.; Zhao, W. Gallic acid as a selective anticancer agent that induces apoptosis in SMMC-7721 human hepatocellular carcinoma cells. Oncol. Lett. 2016, 11, 150-158. [CrossRef]

6. de Lucena, J.D.; Gadelha-Filho, C.V.J.; da Costa, R.O.; de Araujo, D.P.; Lima, F.A.V.; Neves, K.R.T.; de Barros Viana, G.S. L-linalool exerts a neuroprotective action on hemiparkinsonian rats. Naunyn. Schmiedebergs Arch. Pharm. 2020, 393, 1077-1088. [CrossRef]

7. Souto-Maior, F.N.; de Carvalho, F.L.; de Morais, L.C.; Netto, S.M.; de Sousa, D.P.; de Almeida, R.N. Anxiolytic-like effects of inhaled linalool oxide in experimental mouse anxiety models. Pharm. Biochem. Behav. 2011, 100, 259-263. [CrossRef]

8. Souto-Maior, F.N.; Fonseca, D.V.; Salgado, P.R.; Monte, L.O.; de Sousa, D.P.; de Almeida, R.N. Antinociceptive and anticonvulsant effects of the monoterpene linalool oxide. Pharm. Biol. 2017, 55, 63-67. [CrossRef]

9. Li, X.J.; Yang, Y.J.; Li, Y.S.; Zhang, W.K.; Tang, H.B. alpha-Pinene, linalool, and 1-octanol contribute to the topical anti-inflammatory and analgesic activities of frankincense by inhibiting COX-2. J. Ethnopharmacol. 2016, 179, 22-26. [CrossRef]

10. Laribi, B.; Kouki, K.; M'Hamdi, M.; Bettaieb, T. Coriander (Coriandrum sativum L.) and its bioactive constituents. Fitoterapia 2015, 103, 9-26. [CrossRef]

11. Khan, S.W.; Khatoon, S. Ethnobotanical studies on some useful herbs of Haramosh and Bugrote valleys in Gilgit, northern areas of Pakistan. Pak. J. Bot. 2008, 40, 43.

12. Singletary, K. Coriander: Overview of potential health benefits. Nutr. Today 2016, 51, 151-161. [CrossRef]

13. Mahendra, P.; Bisht, S. Coriandrum sativum: A daily use spice with great medicinal effect. Pharmacogn. J. 2011, 3, 84-88. [CrossRef]

14. World Health Organization. Cardiovascular Diseases. Available online: https://www.who.int/health-topics/cardiovasculardiseases\#tab=tab_1 (accessed on 25 September 2021).

15. Rahman, F.A.; Abdullah, S.S.; Manan, W.; Tan, L.T.; Neoh, C.F.; Ming, L.C.; Chan, K.G.; Lee, L.H.; Goh, B.H.; Salmasi, S.; et al. Efficacy and Safety of Cyclosporine in Acute Myocardial Infarction: A Systematic Review and Meta-Analysis. Front. Pharm. 2018, 9, 238. [CrossRef]

16. Wei, J.N.; Liu, Z.H.; Zhao, Y.P.; Zhao, L.L.; Xue, T.K.; Lan, Q.K. Phytochemical and bioactive profile of Coriandrum sativum L. Food Chem. 2019, 286, 260-267. [CrossRef] [PubMed]

17. Khazdair, M.R.; Anaeigoudari, A.; Hashemzehi, M.; Mohebbati, R. Neuroprotective potency of some spice herbs, a literature review. J. Tradit. Complement. Med. 2019, 9, 98-105. [CrossRef]

18. Sahib, N.G.; Anwar, F.; Gilani, A.H.; Hamid, A.A.; Saari, N.; Alkharfy, K.M. Coriander (Coriandrum sativum L.): A potential source of high-value components for functional foods and nutraceuticals-A review. Phytother. Res. 2013, 27, 1439-1456. [CrossRef] 
19. Chrysant, S.G.; Chrysant, G.S. Herbs Used for the Treatment of Hypertension and their Mechanism of Action. Curr. Hypertens. Rep. 2017, 19, 77. [CrossRef]

20. Hussain, F.; Jahan, N.; Rahman, K.U.; Sultana, B.; Jamil, S. Identification of hypotensive biofunctional compounds of Coriandrum sativum and evaluation of their Angiotensin-Converting Enzyme (ACE) inhibition potential. Oxid. Med. Cell. Longev. 2018, 2018, 4643736. [CrossRef]

21. Agunloye, O.M.; Oboh, G.; Ademiluyi, A.O.; Ademosun, A.O.; Akindahunsi, A.A.; Oyagbemi, A.A.; Omobowale, T.O.; Ajibade, T.O.; Adedapo, A.A. Cardio-protective and antioxidant properties of caffeic acid and chlorogenic acid: Mechanistic role of angiotensin converting enzyme, cholinesterase and arginase activities in cyclosporine induced hypertensive rats. Biomed. Pharm. 2019, 109, 450-458. [CrossRef]

22. Micallef, M.A.; Garg, M.L. Beyond blood lipids: Phytosterols, statins and omega-3 polyunsaturated fatty acid therapy for hyperlipidemia. J. Nutr. Biochem. 2009, 20, 927-939. [CrossRef]

23. Oliveira, J.R.; Ribeiro, G.H.M.; Rezende, L.F.; Fraga-Silva, R.A. Plant Terpenes on Treating Cardiovascular and Metabolic Disease: A Review. Protein Pept. Lett. 2021, 28, 750-760. [CrossRef]

24. Al-Snafi, A.E. A review on chemical constituents and pharmacological activities of Coriandrum sativum. IOSR J. Pharm. 2016, 6, 17-42. [CrossRef]

25. Diederichsen, A. Coriander: Coriandrum sativum L.; Bioversity International: Rome, Italy, 1996; Volume 3.

26. Nair, V.; Singh, S.; Gupta, Y.K. Anti-granuloma activity of Coriandrum sativum in experimental models. J. Ayurveda Integr. Med. 2013, 4, 13-18. [CrossRef]

27. Paniagua-Zambrana, N.Y.; Bussmann, R.W.; Romero, C. Coriandrum sativum L. A piaceae. Ethnobot. Andes 2020, 1-7. [CrossRef]

28. Musselman, L.J. Encyclopedia of Common Natural Ingredients Used in Food, Drugs, and Cosmetics, 2nd ed.; Leung, A.T., Foster, S., Eds.; Springer: New York, NY, USA, 1996.

29. Platel, K.; Srinivasan, K. Digestive stimulant action of spices: A myth or reality? Indian J. Med. Res. 2004, 119, 167-179.

30. Otoom, S.; Al-Safi, S.; Kerem, Z.; Alkofahi, A. The use of medicinal herbs by diabetic Jordanian patients. J. Herb. Pharmacother. 2006, 6, 31-41. [CrossRef]

31. Tahraoui, A.; El-Hilaly, J.; Israili, Z.; Lyoussi, B. Ethnopharmacological survey of plants used in the traditional treatment of hypertension and diabetes in south-eastern Morocco (Errachidia province). J. Ethnopharmacol. 2007, 110, 105-117. [CrossRef] [PubMed]

32. Al-Rowais, N.A. Herbal medicine in the treatment of diabetes mellitus. Saudi Med. J. 2002, 23, 1327-1331. [PubMed]

33. Chaudhry, N.; Tariq, P. Bactericidal activity of black pepper, bay leaf, aniseed and coriander against oral isolates. Pak. J. Pharm. Sci. 2006, 19, 214-218.

34. Ugulu, I.; Baslar, S.; Yorek, N.; Dogan, Y. The investigation and quantitative ethnobotanical evaluation of medicinal plants used around Izmir province, Turkey. J. Med. Plants Res. 2009, 3, 345-367.

35. Emamghoreishi, M.; Heidari-Hamedani, G. Anticonvulsant effect of extract and essential oil of Coriandrum sativum seed in conscious mice. Iran. J. Pharm. Res. 2004, 3, 71

36. Emamghoreishi, M.; Heidari-Hamedani, G. Sedative-hypnotic activity of extracts and essential oil of Coriander seeds. Iran. J. Med. Sci. 2006, 31, 22-27.

37. Aissaoui, A.; El-Hilaly, J.; Israili, Z.H.; Lyoussi, B. Acute diuretic effect of continuous intravenous infusion of an aqueous extract of Coriandrum sativum L. in anesthetized rats. J. Ethnopharmacol. 2008, 115, 89-95. [CrossRef]

38. Taherian, A.A.; Vafaei, A.A.; Ameri, J. Opiate system mediate the antinociceptive effects of Coriandrum sativum in mice Iran. J. Pharm. Res. 2012, 11, 679.

39. Wichtl, M. Herbal Drugs and Phytopharmaceuticals: A Handbook for Practice on a Scientific Basis; Wichtl, M., Ed.; Medpharm GmbH Scientific Publishers: Stuttgart, Germany, 2004.

40. Khare, C.P. Indian Medicinal Plants: An Illustrated Dictionary; Springer Science \& Business Media: Berlin/Heidelberg, Germany, 2008.

41. Grieve, M. A Modern Herbal; Courier Corporation: North Chelmsford, MA, USA, 2013; Volume 2.

42. Hassar, M. La phytothérapie au Maroc. Espérance Médicale 1999, 6, 83-85.

43. Bashir, S.; Safdar, A. Coriander Seeds: Ethno-medicinal, Phytochemical and Pharmacological Profile. Sci. Spices Culin. Herbs-Latest Lab. Pre-Clin. Clin. Stud. 2020, 2, 39-64.

44. Chauhan, P.; Jaryal, M.; Kumari, K.; Singh, M. Phytochemical and in vitro Antioxidant Potential of Aqueous Leaf Extracts of Brassica juncea and Coriandrum sativum; World Vegetable Center: Tainan, Taiwan, 2012.

45. Ishikawa, T.; Kondo, K.; Kitajima, J. Water-soluble constituents of coriander. Chem. Pharm. Bull. 2003, 51, 32-39. [CrossRef]

46. Barros, L.; Duenas, M.; Dias, M.I.; Sousa, M.J.; Santos-Buelga, C.; Ferreira, I.C. Phenolic profiles of in vivo and in vitro grown Coriandrum sativum L. Food Chem. 2012, 132, 841-848. [CrossRef]

47. Oganesyan, E.; Nersesyan, Z.; Parkhomenko, A.Y. Chemical composition of the above-ground part of Coriandrum sativum. Pharm. Chem. J. 2007, 41, 149-153. [CrossRef]

48. Rahimi, A.R.; Babaei, S.; Mashayekhi, K.; Rokhzadi, A.; Amini, S. Anthocyanin content of coriander (Coriandrum sativum L.) leaves as affected by salicylic acid and nutrients application. IJB 2013, 3, 141-145. [CrossRef]

49. Patel, D.K.; Desai, S.N.; Gandhi, H.P.; Devkar, R.V.; Ramachandran, A.V. Cardio protective effect of Coriandrum sativum L. on isoproterenol induced myocardial necrosis in rats. Food Chem. Toxicol. 2012, 50, 3120-3125. [CrossRef] [PubMed] 
50. Jabeen, Q.; Bashir, S.; Lyoussi, B.; Gilani, A.H. Coriander fruit exhibits gut modulatory, blood pressure lowering and diuretic activities. J. Ethnopharmacol. 2009, 122, 123-130. [CrossRef] [PubMed]

51. Rehman, N.; Jahan, N.; ul-Rahman, K.; Khan, K.M.; Zafar, F. Anti-arrhythmic potential of Coriandrum sativum seeds in salt induced arrhythmic rats. Pak. Vet. J. 2016, 36, 465-471.

52. Shrirame, B.; Geed, S.; Raj, A.; Prasad, S.; Rai, M.; Singh, A.; Singh, R.; Rai, B. Optimization of Supercritical Extraction of Coriander (Coriandrum sativum L.) Seed and Characterization of Essential Ingredients. J. Essent. Oil Bear. Plants 2018, 21, 330-344. [CrossRef]

53. Coelho, J.P.; Cristino, A.F.; Matos, P.G.; Rauter, A.P.; Nobre, B.P.; Mendes, R.L.; Barroso, J.G.; Mainar, A.; Urieta, J.S.; Fareleira, J.M.; et al. Extraction of volatile oil from aromatic plants with supercritical carbon dioxide: Experiments and modeling. Molecules 2012, 17, 10550-10573. [CrossRef]

54. Sourmaghi, M.H.; Kiaee, G.; Golfakhrabadi, F.; Jamalifar, H.; Khanavi, M. Comparison of essential oil composition and antimicrobial activity of Coriandrum sativum L. extracted by hydrodistillation and microwave-assisted hydrodistillation J. Food Sci. Technol. 2015, 52, 2452-2457. [CrossRef]

55. Coşkuner, Y.; Karababa, E. Physical properties of coriander seeds (Coriandrum sativum L.). J. Food Eng. 2007, 80, 408-416. [CrossRef]

56. Burdock, G.A.; Carabin, I.G. Safety assessment of coriander (Coriandrum sativum L.) essential oil as a food ingredient. Food Chem. Toxicol. 2009, 47, 22-34. [CrossRef]

57. Msaada, K.; Hosni, K.; Taarit, M.B.; Chahed, T.; Kchouk, M.E.; Marzouk, B. Changes on essential oil composition of coriander (Coriandrum sativum L.) fruits during three stages of maturity. Food Chem. 2007, 102, 1131-1134. [CrossRef]

58. Zoubiri, S.; Baaliouamer, A. Essential oil composition of Coriandrum sativum seed cultivated in Algeria as food grains protectant. Food Chem. 2010, 122, 1226-1228. [CrossRef]

59. Nejad Ebrahimi, S.; Hadian, J.; Ranjbar, H. Essential oil compositions of different accessions of Coriandrum sativum L. from Iran Nat. Prod. Res. 2010, 24, 1287-1294. [CrossRef] [PubMed]

60. Bhuiyan, M.N.I.; Begum, J.; Sultana, M. Chemical composition of leaf and seed essential oil of Coriandrum sativum L. from Bangladesh. Bangladesh J. Pharmacol. 2009, 4, 150-153. [CrossRef]

61. Eikani, M.H.; Golmohammad, F.; Rowshanzamir, S. Subcritical water extraction of essential oils from coriander seeds (Coriandrum sativum L.). J. Food Eng. 2007, 80, 735-740. [CrossRef]

62. Msaada, K.; Taârit, M.B.; Hosni, K.; Salem, N.; Tammar, S.; Bettaieb, I.; Hammami, M.; Limam, F.; Marzouk, B. Comparison of Different Extraction Methods for the Determination of Essential oils and Related Compounds from Coriander (Coriandrum sativum L.). Acta Chim. Slov. 2012, 59, 803-813.

63. Benyoussef, E.H.; Saibi, S. Influence of essential oil composition on water distillation kinetics. Flavour Fragr. J. 2013, 28, 300-308. [CrossRef]

64. HuaSong, S.; Yue, Z.; WenZhong, Z.; ShengQiang, D.; Kai, S.; ZhongXiao, T.; Yan, Y.; Ying, H. Changes of volatile components in Eryngium foetidum L. and Yunnan Coriandrum sativum L. with different plant organs. Food Res. Dev. 2016, 37, $161-165$.

65. Chung, I.-M.; Ahmad, A.; Kim, S.-J.; Naik, P.M.; Nagella, P. Composition of the essential oil constituents from leaves and stems of Korean Coriandrum sativum and their immunotoxicity activity on the Aedes aegypti L. Immunopharmacol. Immunotoxicol. 2012, 34, 152-156. [CrossRef] [PubMed]

66. Orav, A.; Arak, E.; Raal, A. Essential oil composition of Coriandrum sativum L. fruits from different countries. J. Essent. Oil Bear. Plants 2011, 14, 118-123. [CrossRef]

67. Gil, A.; De La Fuente, E.B.; Lenardis, A.E.; López Pereira, M.; Suárez, S.A.; Bandoni, A.; Van Baren, C.; Di Leo Lira, P.; Ghersa, C.M. Coriander essential oil composition from two genotypes grown in different environmental conditions. J. Agric. Food Chem. 2002, 50, 2870-2877. [CrossRef]

68. Saygi, K.O. Quantification of Phenolics from Coriandrum sativum vulgare and Coriandrum sativum microcarpum by HPLC-DAD. Iran. J. Sci. Technol. Trans. A Sci. 2021, 45, 1319-1326. [CrossRef]

69. Divya, P.; Puthusseri, B.; Neelwarne, B. Carotenoid content, its stability during drying and the antioxidant activity of commercial coriander (Coriandrum sativum L.) varieties. Food Res. Int. 2012, 45, 342-350. [CrossRef]

70. Sriti, J.; Wannes, W.A.; Talou, T.; Mhamdi, B.; Hamdaoui, G.; Marzouk, B. Lipid, fatty acid and tocol distribution of coriander fruit's different parts. Ind. Crops Prod. 2010, 31, 294-300. [CrossRef]

71. Sriti, J.; Talou, T.; Wannes, W.A.; Cerny, M.; Marzouk, B. Essential oil, fatty acid and sterol composition of Tunisian coriander fruit different parts. J. Sci. Food Agric. 2009, 89, 1659-1664. [CrossRef]

72. Suttisansanee, U.; Thiyajai, P.; Chalermchaiwat, P.; Wongwathanarat, K.; Pruesapan, K.; Charoenkiatkul, S.; Temviriyanukul, P. Phytochemicals and In Vitro Bioactivities of Aqueous Ethanolic Extracts from Common Vegetables in Thai Food. Plants 2021, 10, 1563. [CrossRef]

73. Kajal, A.; Singh, R. Coriandrum sativum seeds extract mitigate progression of diabetic nephropathy in experimental rats via AGEs inhibition. PLoS ONE 2019, 14, e0213147. [CrossRef] [PubMed]

74. Singh, R.; Kaur, N.; Kishore, L.; Gupta, G.K. Management of diabetic complications: A chemical constituents based approach. J. Ethnopharmacol. 2013, 150, 51-70. [CrossRef] [PubMed]

75. Hajlaoui, H.; Arraouadi, S.; Noumi, E.; Aouadi, K.; Adnan, M.; Khan, M.A.; Kadri, A.; Snoussi, M. Antimicrobial, Antioxidant, Anti-Acetylcholinesterase, Antidiabetic, and Pharmacokinetic Properties of Carum carvi L. and Coriandrum sativum L. Essential Oils Alone and in Combination. Molecules 2021, 26, 3625. [CrossRef] 
76. Cha, J.M.; Yoon, D.; Kim, S.Y.; Kim, C.S.; Lee, K.R. Neurotrophic and anti-neuroinflammatory constituents from the aerial parts of Coriandrum sativum. Bioorganic Chem. 2020, 105, 104443. [CrossRef] [PubMed]

77. Ramadan, M.F.; Amer, M.M.A.; Awad, A.E.S. Coriander (Coriandrum sativum L.) seed oil improves plasma lipid profile in rats fed a diet containing cholesterol. Eur. Food Res. Technol. 2008, 227, 1173-1182. [CrossRef]

78. Ananthan, R.; Latha, M.; Ramkumar, K.; Pari, L.; Baskar, C.; Bai, V.N. Modulatory effects of Gymnema montanum leaf extract on alloxan-induced oxidative stress in Wistar rats. Nutrition 2004, 20, 280-285. [CrossRef] [PubMed]

79. Sharma, N.; Sharma, P.; Jasuja, N.D.; Joshi, S.C. Ameliorative efficiency of Coriandrum sativum seed extract on atherosclerosis and oxidative stress in male albino hyperlipidemic rabbits. Res. J. Pharm. Biol. Chem. Sci. 2014, 5, $26-39$.

80. Lal, A.A.; Kumar, T.; Murthy, P.B.; Pillai, K.S. Hypolipidemic effect of Coriandrum sativum L. in triton-induced hyperlipidemic rats. Indian J. Exp. Biol. 2004, 42, 909-912. [PubMed]

81. Zeb, F.; Safdar, M.; Fatima, S.; Khan, S.; Alam, S.; Muhammad, M.; Syed, A.; Habib, F.; Shakoor, H. Supplementation of garlic and coriander seed powder: Impact on body mass index, lipid profile and blood pressure of hyperlipidemic patients. Pak. J. Pharm. Sci. 2018, 31, 1935-1941.

82. Rajeshwari, U.; Shobha, I.; Andallu, B. Comparison of aniseeds and coriander seeds for antidiabetic, hypolipidemic and antioxidant activities. Spatula DD Peer Rev. J. Complement. Med. Drug Discov. 2011, 1, 9-16. [CrossRef]

83. Aissaoui, A.; Zizi, S.; Israili, Z.H.; Lyoussi, B. Hypoglycemic and hypolipidemic effects of Coriandrum sativum L. in Meriones shawi rats. J. Ethnopharmacol. 2011, 137, 652-661. [CrossRef]

84. Chaudhary, S.K.; Maity, N.; Nema, N.K.; Bhadra, S.; Saha, B.P.; Mukherjee, P.K. Angiotensin converting enzyme inhibition activity of fennel and coriander oils from India. Nat. Prod. Commun. 2013, 8, 671-672. [CrossRef]

85. Afsheen, N.; Khalil Ur, R.; Jahan, N.; Khan, K.M.; Zia, M.A. Optimization of cardioprotective potential of various concentrations of medicinal plants by using response surface methodology. Pak. Vet. J. 2019, 39, 13-18. [CrossRef]

86. Dhanapakiam, P.; Joseph, J.M.; Ramaswamy, V.K.; Moorthi, M.; Kumar, A.S. The cholesterol lowering property of coriander seeds (Coriandrum sativum): Mechanism of action. J. Environ. Biol. 2008, 29, 53-56.

87. Dhyani, N.; Parveen, A.; Siddiqi, A.; Hussain, M.E.; Fahim, M. Cardioprotective Efficacy of Coriandrum sativum (L.) Seed Extract in Heart Failure Rats Through Modulation of Endothelin Receptors and Antioxidant Potential. J. Diet. Suppl. 2020, 17, 13-26. [CrossRef]

88. Chithra, V.; Leelamma, S. Hypolipidemic effect of coriander seeds (Coriandrum sativum): Mechanism of action. Plant Foods Hum. Nutr. 1997, 51, 167-172. [CrossRef]

89. Patel, D.; Desai, S.; Gajaria, T.; Devkar, R.; Ramachandran, A.V. Coriandrum sativum L. seed extract mitigates lipotoxicity in raw 264.7 cells and prevents atherogenic changes in rats. EXCLI J. 2013, 12, 313-334.

90. Kousar, S.; Jahan, N.; Khalil Ur, R.; Nosheen, S. Antilipidemic activity of Coriandrum sativum. Biosci. Res. 2011, 8, 8-14.

91. Wang, X.; Zhu, C.; Peng, T.; Zhang, W.; Zhang, J.; Liu, H.; Wu, C.; Pan, X.; Wu, C. Enhanced stability of an emulsion enriched in unsaturated fatty acids by dual natural antioxidants fortified in both the aqueous and oil phases. Food Hydrocoll. 2018, 82, 322-328. [CrossRef]

92. Froyen, E. The effects of fat consumption on low-density lipoprotein particle size in healthy individuals: A narrative review. Lipids Health Dis. 2021, 20, 86. [CrossRef] [PubMed]

93. Bays, H. Clinical overview of Omacor: A concentrated formulation of omega-3 polyunsaturated fatty acids. Am. J. Cardiol. 2006, 98, 71i-76i. [CrossRef] [PubMed]

94. Colin, A.; Reggers, J.; Castronovo, V.; Ansseau, M. Lipids, depression and suicide. Encephale 2003, $29,49-58$.

95. Bao, L.; Hu, L.; Zhang, Y.; Wang, Y.I. Hypolipidemic effects of flavonoids extracted from Lomatogonium rotatum. Exp. Med. 2016, 11, 1417-1424. [CrossRef]

96. Plösch, T.; Kruit, J.K.; Bloks, V.W.; Huijkman, N.C.; Havinga, R.; Duchateau, G.S.; Lin, Y.; Kuipers, F. Reduction of cholesterol absorption by dietary plant sterols and stanols in mice is independent of the Abcg5/8 transporter. J. Nutr. 2006, 136, 2135-2140 [CrossRef]

97. Hwang, G.-H.; Heo, Y.-R.; Lee, H.-J.; Park, O.-J.; Kang, S.-K.; Kim, Y.-D. Effects of Coriandrum sativum L. on lipid metabolism in rats with hypertriglyceridemic diet. Nutr. Sci. 2001, 4, 13-19.

98. Sriti, J.; Wannes, W.A.; Talou, T.; Mhamdi, B.; Cerny, M.; Marzouk, B. Lipid profiles of Tunisian coriander (Coriandrum sativum) seed. J. Am. Oil Chem. Soc. 2010, 87, 395-400. [CrossRef]

99. Batta, A.K.; Xu, G.; Honda, A.; Miyazaki, T.; Salen, G. Stigmasterol reduces plasma cholesterol levels and inhibits hepatic synthesis and intestinal absorption in the rat. Metabolism 2006, 55, 292-299. [CrossRef]

100. Kong, C.K.; Low, L.E.; Siew, W.S.; Yap, W.H.; Khaw, K.Y.; Ming, L.C.; Mocan, A.; Goh, B.H.; Goh, P.H. Biological Activities of Snowdrop (Galanthus spp., Family Amaryllidaceae). Front. Pharm. 2020, 11, 552453. [CrossRef]

101. Anmol, R.J.; Marium, S.; Hiew, F.T.; Han, W.C.; Kwan, L.K.; Wong, A.K.Y.; Khan, F.; Sarker, M.M.R.; Chan, S.Y.; Kifli, N.; et al. Phytochemical and Therapeutic Potential of Citrus grandis (L.) Osbeck: A Review. J. Evid. Based Integr. Med. 2021, 26. [CrossRef] [PubMed]

102. Weber, C.; Noels, H. Atherosclerosis: Current pathogenesis and therapeutic options. Nat. Med. 2011, 17, 1410-1422. [CrossRef] [PubMed]

103. Glass, C.K.; Witztum, J.L. Atherosclerosis: The road ahead. Cell 2001, 104, 503-516. [CrossRef] 
104. Greaves, D.R.; Gough, P.J.; Gordon, S. Recent progress in defining the role of scavenger receptors in lipid transport, atherosclerosis and host defence. Curr. Opin. Lipidol. 1998, 9, 425-432. [CrossRef]

105. Björkerud, B.; Björkerud, S.r. Contrary effects of lightly and strongly oxidized LDL with potent promotion of growth versus apoptosis on arterial smooth muscle cells, macrophages, and fibroblasts. Arterioscler. Thromb. Vasc. Biol. 1996, 16, $416-424$. [CrossRef]

106. Sreelatha, S.; Inbavalli, R. Antioxidant, antihyperglycemic, and antihyperlipidemic effects of Coriandrum sativum leaf and stem in alloxan-induced diabetic rats. J. Food Sci. 2012, 77, T119-T123. [CrossRef]

107. Dianat, M.; Negin, A.; Mohammad, B.; Yaghoub, F. Antidysrhythmic, inotropic and chronotropic effects of ellagic acid and forced exercise in rat. Res. J. Pharm. Biol. Chem. Sci. 2014, 5, 1549-1557.

108. Ramadan, M.F.; Moersel, J.-T. Screening of the antiradical action of vegetable oils. J. Food Compos. Anal. 2006, 19, 838-842. [CrossRef]

109. Potter, T.L. Essential oil composition of cilantro. J. Agric. Food Chem. 1996, 44, 1824-1826. [CrossRef]

110. Abiko, Y.; Kumagai, Y. Preventive Agents and Phytochemicals for Reducing the Adverse Health Effects of Arsenic. Arsen. Contam. Asia 2019, 151-161. [CrossRef]

111. Mazimba, O. Umbelliferone: Sources, chemistry and bioactivities review. Bull. Fac. Pharm. Cairo Univ. 2017, 55, 223-232. [CrossRef]

112. Ali, F.E.; Hassanein, E.H.; El-Bahrawy, A.H.; Omar, Z.M.; Rashwan, E.K.; Abdel-Wahab, B.A.; Abd-Elhamid, T.H. Nephroprotective effect of umbelliferone against cisplatin-induced kidney damage is mediated by regulation of NRF2, cytoglobin, SIRT1/FOXO-3, and NF-kB-p65 signaling pathways. J. Biochem. Mol. Toxicol. 2021, 35, e22738. [CrossRef]

113. Webster, K.A. Mitochondrial membrane permeabilization and cell death during myocardial infarction: Roles of calcium and reactive oxygen species. Future Cardiol. 2012, 8, 863-884. [CrossRef]

114. Nwagha, U.; Ikekpeazu, E.; Ejezie, F.; Neboh, E.; Maduka, I. Atherogenic index of plasma as useful predictor of cardiovascular risk among postmenopausal women in Enugu, Nigeria. Afr. Health Sci. 2010, 10, 248-252. [PubMed]

115. Boers, M.; Nurmohamed, M.T.; Doelman, C.J.; Lard, L.R.; Verhoeven, A.C.; Voskuyl, A.E.; Huizinga, T.W.; van de Stadt, R.J.; Dijkmans, B.A.; van der Linden, S. Influence of glucocorticoids and disease activity on total and high density lipoprotein cholesterol in patients with rheumatoid arthritis. Ann. Rheum. Dis. 2003, 62, 842-845. [CrossRef]

116. Georgiadis, A.N.; Papavasiliou, E.C.; Lourida, E.S.; Alamanos, Y.; Kostara, C.; Tselepis, A.D.; Drosos, A.A. Atherogenic lipid profile is a feature characteristic of patients with early rheumatoid arthritis: Effect of early treatment-A prospective, controlled study. Arthritis Res. Ther. 2006, 8,1-7. [CrossRef]

117. Pihlanto, A.; Akkanen, S.; Korhonen, H.J. ACE-inhibitory and antioxidant properties of potato (Solanum tuberosum). Food Chem. 2008, 109, 104-112. [CrossRef]

118. Daskaya-Dikmen, C.; Yucetepe, A.; Karbancioglu-Guler, F.; Daskaya, H.; Ozcelik, B. Angiotensin-I-converting enzyme (ACE)inhibitory peptides from plants. Nutrients 2017, 9, 316. [CrossRef]

119. Liu, M.; Du, M.; Zhang, Y.; Xu, W.; Wang, C.; Wang, K.; Zhang, L. Purification and identification of an ACE inhibitory peptide from walnut protein. J. Agric. Food Chem. 2013, 61, 4097-4100. [CrossRef] [PubMed]

120. Nazni, P.; Dharmaligam, R. Isolation and separation of phenolic compound from coriander flowers. Int. J. Agric. Food Sci. 2014, 4, 13-21.

121. Rajeshwari, C.; Andallu, B. Isolation and simultaneous detection of flavonoids in the methanolic and ethanolic extracts of Coriandrum sativum L. seeds by RP-HPLC. Pak. J. Food Sci. 2011, 21, 13-21.

122. Msaada, K.; Jemia, M.B.; Salem, N.; Bachrouch, O.; Sriti, J.; Tammar, S.; Bettaieb, I.; Jabri, I.; Kefi, S.; Limam, F. Antioxidant activity of methanolic extracts from three coriander (Coriandrum sativum L.) fruit varieties. Arab. J. Chem. 2017, 10, S3176-S3183. [CrossRef]

123. Luo, J.; Zhang, C.; Liu, Q.; Ou, S.; Zhang, L.; Peng, X. Combinative effect of sardine peptides and quercetin alleviates hypertension through inhibition of angiotensin I converting enzyme activity and inflammation. Food Res. Int. 2017, 100, 579-585. [CrossRef] [PubMed]

124. Oyagbemi, A.A.; Omobowale, T.O.; Ola-Davies, O.E.; Asenuga, E.R.; Ajibade, T.O.; Adejumobi, O.A.; Afolabi, J.M.; Ogunpolu, B.S.; Falayi, O.O.; Ayodeji, F. Ameliorative effect of Rutin on sodium fluoride-induced hypertension through modulation of Kim-1/NF-кB/Nrf2 signaling pathway in rats. Environ. Toxicol. 2018, 33, 1284-1297. [CrossRef] [PubMed]

125. Gao, H.-L.; Yu, X.-J.; Hu, H.-B.; Yang, Q.-W.; Liu, K.-L.; Chen, Y.-M.; Zhang, Y.; Zhang, D.-D.; Tian, H.; Zhu, G.-Q. Apigenin Improves Hypertension and Cardiac Hypertrophy Through Modulating NADPH Oxidase-Dependent ROS Generation and Cytokines in Hypothalamic Paraventricular Nucleus. Cardiovasc. Toxicol. 2021, 21, 721-736. [CrossRef]

126. Oyagbemi, A.A.; Omobowale, T.O.; Ola-Davies, O.E.; Asenuga, E.R.; Ajibade, T.O.; Adejumobi, O.A.; Afolabi, J.M.; Ogunpolu, B.S.; Falayi, O.O.; Saba, A.B.; et al. Luteolin-mediated Kim-1/NF-kB/Nrf2 signaling pathways protects sodium fluoride-induced hypertension and cardiovascular complications. Biofactors 2018, 44, 518-531. [CrossRef] [PubMed]

127. Loizzo, M.R.; Said, A.; Tundis, R.; Rashed, K.; Statti, G.A.; Hufner, A.; Menichini, F. Inhibition of angiotensin converting enzyme (ACE) by flavonoids isolated from Ailanthus excelsa (Roxb)(Simaroubaceae). Phytother. Res. Int. J. Devoted Pharmacol. Toxicol. Eval. Nat. Prod. Deriv. 2007, 21, 32-36.

128. Chen, C.-H.; Lin, J.-Y.; Lin, C.-N.; Hsu, S.-Y. Inhibition of angiotensin-I-converting enzyme by tetrahydroxyxanthones isolated from Tripterospermum lanceolatum. J. Nat. Prod. 1992, 55, 691-695. [CrossRef] 
129. Bormann, H.; Melzig, M. Inhibition of metallopeptidases by flavonoids and related compounds. Die Pharm. 2000, 55, 129-132.

130. Lacaille-Dubois, M.; Franck, U.; Wagner, H. Search for potential angiotensin converting enzyme (ACE)-inhibitors from plants. Phytomedicine 2001, 8, 47-52. [CrossRef] [PubMed]

131. Epstein, M. Calcium Antagonists in Clinical Medicine; Hanley Belfus Inc.: Phila, PA, USA, 1992; Volume 183.

132. Chiu, A.T.; McCall, D.E.; Timmermans, P.B. Pharmacological characteristics of receptor-operated and potential-operated Ca ${ }^{2+}$ channels in rat aorta. Eur. J. Pharmacol. 1986, 127, 1-8. [CrossRef]

133. Mendel, B.; Christianto; Setiawan, M.; Prakoso, R.; Siagian, S.N. A Comparative Effectiveness Systematic Review and MetaAnalysis of Drugs for the Prophylaxis of Junctional Ectopic Tachycardia. Curr. Cardiol. Rev. 2021. [CrossRef] [PubMed] 